\title{
The International Bank Lending Channel of Monetary Policy Rates and QE: Credit Supply, Reach-for-Yield, and Real Effects
}

\author{
Bernardo Morais, José-Luis Peydró, Jessica Roldán-Peña, and Claudia Ruiz-Ortega*
}

\begin{abstract}
We identify the international credit channel by exploiting Mexican supervisory data sets and foreign monetary policy shocks in a country with a large presence of European and U.S. banks. A softening of foreign monetary policy expands credit supply of foreign banks (e.g., U.K. policy affects credit supply in Mexico via U.K. banks), inducing strong firm-level real effects. Results support an international risk-taking channel and spill overs of core countries' monetary policies to emerging markets, both in the foreign monetary softening part (with higher credit and liquidity risk-taking by foreign banks) and in the tightening part (with negative local firm-level real effects).

JEL codes: E52, E58, G01, G21, G28.

Keywords: monetary policy, financial globalization, quantitative easing (QE), credit supply, risk-taking, foreign banks.

\footnotetext{
* This draft is from October 2018. Bernardo Morais: Federal Reserve Board, bernardo.c.morais@frb.gov (contact author); José-Luis Peydró: ICREA-Universitat Pompeu Fabra, CREI, Barcelona GSE, Imperial College, CEPR, jose.peydro@upf.edu; Jessica Roldán-Peña: Banco de México, jroldan@banxico.org.mx; and Claudia Ruiz-Ortega: DECFP, World Bank, cruizortega@worldbank.org. We are grateful to Banco de México, in particular to Ana Aguilar and Adrián De la Garza, for their support of this project. We thank Gabriel Chodorow-Reich, Daniel Dias, Mark Gertler, Peter Karadi, Fabrizio Lopez-Gallo Dey, Soledad Martinez-Peria, Victoria Nuguer, Pascual O'Dogherty, Raghuram Rajan, Hélène Rey, John Rogers, Andrei Shleifer, Jeremy Stein, André Trindade, conference participants at the NBER Summer Institute in Finance-Macro and Monetary Economics, and the seminar participants at Bank of England, Banca d'Italia, Banco de México, Banco de Portugal, CREI, Istituto Einaudi, Oxford University, World Bank, Vanderbilt University and the Federal Reserve Board for helpful comments. We thank Carlos Zarazúa for outstanding research assistance. The views in this paper are solely the responsibility of the authors and should not be interpreted as reflecting the views of the Board of Governors of the Federal Reserve System or of any other person associated with the Federal Reserve System, the World Bank, or Banco de México. Banco de México requested to review the results of the study prior to dissemination to ensure confidentiality of the data. Peydró acknowledges financial support from project ECO2012-32434 of the Spanish Ministry of Economics and Competitiveness and the European Research Council Grant (project 648398).
} 
The recent global financial crisis, as well as other previous crises, have shown that bank credit cycles have a significant effect on the economy, financial globalization can impact financial stability, and monetary policy may be a key public policy tool (Bernanke (1983), Reinhart and Rogoff (2009), Schularick and Taylor (2012)). Strong bank credit growth, especially that financed by foreign liabilities, is the most important predictor of financial crises (Jorda, Schularick, and Taylor, (2011), Gourinchas and Obstfeld, (2012)), which are in general accompanied by bank credit crunches and sudden stops of foreign capital (Bernanke and Lown (1991), Calvo and Reinhart (2000)). Moreover, as Rey (2013) argued at the Federal Reserve's annual conference in Jackson Hole, monetary policy set by the Federal Reserve may have substantial spillovers in emerging markets' credit cycles, generating an international risk-taking channel of monetary policy. In line with this view, the Federal Reserve Vice Chairman Stanley Fischer (2014), warned about international spillovers that both interest rate and quantitative easing (QE) may have, pointing out that European monetary policy also plays an important role, as European banks are strongly globalized, and emerging market central bankers such as Raghuram Rajan (2014) Reserve Bank of India Governor, have expressed concern about the spillovers of U.S. and Europe's monetary policy on the financial stability of their economies.

In this paper we study the international credit and risk-taking channel of monetary policy, in particular, the effect of core countries' monetary policy on emerging markets' credit cycles. More specifically, we analyze (i) whether foreign monetary policy affects the supply of credit from foreign banks to local firms, (ii) whether foreign monetary policy shocks have real effects in terms of firm investment, employment, and survival, or whether local firms are able to reduce the effects of such shocks by substituting credit with local banks or with other sources of finance, (iii) whether an expansive foreign monetary policy creates an international risk-taking channel by affecting global banks' reach-for-yield incentives, (iv) whether these effects depend on the type of monetary policy used, that is policy rates versus QE, and (v) whether foreign and local banks finance local credit expansion differently.

Despite the importance of these questions for policy and macro-finance, identification of the effect of foreign monetary policies on the credit and risk-taking channel by foreign banks has not been possible, due to a lack of comprehensive credit registry data, that can be matched to firm and bank information, over a sufficiently long period to analyze monetary policy. As we explain below, a matched credit-firm data set is necessary to identify and analyze credit supply, including risk- 
taking and reach-for-yield, as well as the associated real effects of credit supply. Moreover, while foreign banks are important around the world, they are even more so in emerging markets and developing countries where they account for around 50\% of the market share in terms of loans, deposits, and profits (Claessens and van Horen (2012)).

We overcome these hurdles by using proprietary data from the Mexican banking supervisor. These data contain all business loans over the 2001 to 2015 period, and are matched with firm balance sheet information, (including for example firm investment and employment) as well as bank information on ownership and funding. Importantly, this data set includes all new and outstanding commercial loans at a monthly frequency from all banks in Mexico, as well as relevant loan terms, including loan rates (which are absent from most credit registers around the world). Moreover, loans issued by foreign banks in Mexico (owned by U.S. and Eurozone and U.K. investors) is important, as the credit these banks extend to Mexican firms represents roughly $60 \%$ of all commercial bank credit in Mexico (which is similar to other emerging markets as shown by Claessens and van Horen (2012)).

To identify the credit and risk-taking channels of monetary policy (Bernanke and Gertler (1995), Kashyap and Stein (2000), Stein (1998, 2011), Adrian and Shin (2011), Rey (2013)), we analyze loan-level data at the monthly frequency with borrower (or borrower*month) fixed effects. This allows us to control for unobserved (time-varying) firm fundamentals such as investment opportunities or risk that proxy for credit demand, given that foreign banks may lend to different types of firms (Khwaja and Mian (2008), Mian (2006)). Since only 21\% of all firms borrow from multiple banks in a given period, in some specifications we use firm*bank and state*industry*month fixed effects to include firms that, in a given period borrow only from one bank. Note that as period fixed effects control for unobserved global shocks, identification also comes in a given month from differential monetary policies between Mexico, the U.S., the U.K., and the Eurozone. ${ }^{1}$ To identify the risk-taking channel of monetary policy, we classify borrowers into high- and low-yield groups based on their ex-ante loan rates and analyze changes in credit supply, including ex-post loan defaults.

\footnotetext{
${ }^{1}$ Our results suggest similar borrower-observable fundamentals among foreign and local banks and strong exogeneity of firm fundamentals to bank shocks (Altonji, Elder, and Taber (2005)), since, despite the huge increase in $\mathrm{R}^{2}$ due to unobservables, our estimated coefficients do not change if we control for firm*period rather than state*industry*period fixed effects.
} 
To identify the associated real effects, we analyze total bank credit and total (bank and nonbank) firm-level credit availability as well as the dynamics of firm assets, net investment, employment, and a proxy to firm survival due to loan defaults. Analyzing firm-level credit is key as firms could potentially minimize the international monetary policy shocks by substituting their current credit suppliers with credit from other banks or from other sources of finance. Furthermore, in contrast to papers that analyze local monetary policy on local credit conditions, we examine European and U.S. monetary policies, which are exogenous to the Mexican economy. For monetary rates, we use a measure of Taylor rule-type shocks. For QE, we use the change in the balance sheets of U.S., U.K., and Eurozone central banks as a share of GDP. ${ }^{2}$

We find the following robust results. A foreign policy rate shock affects the supply of credit to Mexican firms mainly via their respective foreign banks in Mexico: U.S., U.K., and Eurozone monetary policies impact the supply of credit to Mexican firms mostly through U.S., U.K., and Eurozone banks, respectively. Furthermore, all loan terms are significantly affected, reinforcing the supply driven channel, although the effects are weaker for loan rates. Overall, a one-standarddeviation reduction in foreign monetary policy rates increases the credit volume supplied by foreign banks in Mexico by around 2.1\%, lengthens the loan maturity by $6.7 \%$, and increases the probability of future loan default (delinquencies) over the next year by $9.8 \%$, while a one-standard-deviation reduction in the Mexican policy rate raises the loan volume on average by only $0.6 \%$, but for all banks (national and foreign). ${ }^{3}$

We also find that foreign QE has an expansionary effect on the supply of credit to Mexican firms. More specifically, QE originated in the U.S. and the U.K. mainly works through U.S. and U.K. banks, respectively, in Mexico (primarily on credit volume and maturity). Moreover, an increase in foreign QE is related to an increase in loan defaults from Mexican firms to foreign banks over the following year. However, the QE economic magnitudes tend to be lower than those of changes in policy rates. For instance, for U.S. monetary policy, which has the largest economic

\footnotetext{
${ }^{2}$ To address concerns about potential endogeneity of foreign monetary policy, (i) we use a proxy for a Taylor rule-type shock, (ii) we control for foreign economic activity in interactions with our main variables, including current and expected annual GDP growth, inflation, and financial risk, and (iii) we instrument for foreign monetary policy. Note that while the Fed and the Bank of England (BoE) pursued explicitly QE as a key nonstandard monetary policy, the European Central Bank (ECB) main non-standard monetary policy until 2015 was the full provision of liquidity to banks (ECB $(2009,2011))$.

${ }^{3}$ This could be because, similar to domestic banks, foreign bank subsidiaries in Mexico have large local retail deposits, and therefore, foreign subsidiaries are also affected by the domestic monetary policy. Note that we summarize the results for softening, but we do not find any statistically significant asymmetric effects, except for expansive nonstandard monetary policy on higher loan defaults.
} 
effects, whereas a one-standard-deviation decrease (increase) in the Fed Funds rate (QE) expands credit volume of U.S. banks by $6 \%(2.5 \%)$ and maturity by $9.9 \%(7.1 \%){ }^{4}$

We also analyze implications of changes in monetary policy at the firm level. While loanlevel analysis is needed to identify the supply of credit, including risk-taking, firm-level data are necessary to analyze the substitution of different sources of finance and the associated real effects. ${ }^{5}$ We find that the international monetary policy channel has significant real effects, with stronger elasticities from monetary rates than QE. In particular, a one-standard-deviation softening of foreign monetary rate leads to increases of total bank credit volume of $1.5 \%$, average loan maturity of $4.9 \%$, future default rates of $5.3 \%$, firm liabilities of $1.2 \%$, total assets of $0.7 \%$, net investment of $0.5 \%$, employment of $0.4 \%$, and probability of firm survival of one percentage point. ${ }^{6}$ In contrast, a softening of one-standard-deviation in QE increases future loan defaults on banks at the firm level by $6.5 \%$ but without significant real effects. ${ }^{7}$

Finally, expansive monetary policy leads to important heterogeneous effects of credit supply. Quantitative effects of the international channel are strongest for local corporate borrowers with higher ex-ante loan rates, which proxy for reach-for-yield, with foreign banks engaging in this risktaking more when foreign monetary policy is expansive. This finding is present along all credit dimensions. For borrowers with high ex-ante loan rates (higher than the average), the ex-post default rates associated with a one-standard-deviation reduction in foreign monetary policy increase by $11.7 \%$, whereas for the remaining borrowers there is a zero effect. Likewise, a one-standarddeviation expansion of QE leads to an $8.6 \%$ increase in the future default rate of firms with higher ex-ante loan rates, with a substantially smaller effect on firms with lower ex-ante loan rates. Hence, greater risk-taking is associated with ex-ante observable variables (previous high loan rates) and

\footnotetext{
${ }^{4}$ The speed of transmission of both types of monetary policy shocks is weaker after 12 to 15 months. With the effects generally strongest between six and 12 months (e.g., the effects on loan volume, rates, and defaults peak at around 12 months). Note, that for QE, results are stronger the lower the CDS of the sovereign where the foreign bank is headquartered, which may explain why QE elasticities are lower, especially for Euro-area banks that suffered a sovereign debt crisis.

${ }^{5}$ As in the loan-level regressions, controlling for firm*month versus state*industry*month fixed effects provides very similar coefficients, while the firm-level regressions (where we can only include firm and state*industry*period fixed effects) provide the credit availability channel. Note that results at the loan level are very similar for exporters versus non-exporters.

${ }^{6}$ It also leads to a decrease of $0.1 \%$ in loan interest rates. Note that because bank-firm relationships are highly persistent, with only $9 \%$ of firms switching their main bank from one year to the next, firms are affected by shocks to the banks they were dealing with in the previous period, and hence by the monetary policy affecting those banks. In addition to defaults (delinquencies) at the loan level, we also analyze a proxy for firm survival/exit due to credit defaults.

${ }^{7}$ Apart from the crisis effects measured by CDS (see a previous footnote), QE results are lower due to high standard errors in firm-year data; for example, firm-level results on loan outcomes using monthly-level data are all statistically significant.
} 
with higher ex-post defaults. Overall evidence suggests an international risk-taking channel of monetary policy through foreign monetary policy rates and QE.

At the bank level, we find that when foreign monetary policy is softer, foreign subsidiaries take on more liabilities (especially foreign and short-term), observe more loan defaults, and higher expansion of the balance sheet. Hence, our results are consistent with banks taking on greater liquidity risk (with higher bank funding via foreign bank liabilities, which tend to be more fragile) and greater credit risk (providing more credit to riskier ex-ante and ex-post borrowers) and despite shorter-term foreign liabilities, lending at longer maturities on the asset side of their balance sheet.

The results are consistent with spillovers of core countries' monetary policies to emerging markets, both in the foreign monetary softening part (with higher liquidity and credit risk taken by foreign banks) and in the tightening part (with negative local firm-level real effects). When U.S. and European monetary policies are softer, global banks have more liquidity but lower yields in domestic markets, so they expand to emerging markets reaching for higher yield, with higher credit and liquidity risk-taking, and thus create a local credit boom. When monetary policy becomes tighter, they withdraw from emerging markets, creating a credit crunch with negative firm-level real effects.

Our key contribution is identification of the international risk-taking and credit channel of monetary policy via foreign banks, which allows us to pin down the associated credit supply channel, including spillovers on real effects, and risk-taking, both ex-ante reach-for-yield and expost defaults. In particular, our paper contributes to the literature analyzing the international channel of monetary policy. Cetorelli and Goldberg (2012a, 2012b) provide direct evidence that global banks manage liquidity on a global scale, actively using cross-border internal funding in response to local shocks. We extend this literature by showing that local credit supply, including the associated local real effects and risk-taking, is affected by foreign monetary policy shocks through foreign (global) banks. ${ }^{8}$ It is important to stress that foreign banks are crucial to emerging markets (Claessens and van Horen (2012)). Our findings are important given the recent policy debate about

\footnotetext{
${ }^{8}$ Our paper also contributes to the literature in international banking (Peek and Rosengren (2000), Mian (2006), Acharya and Schnabl (2010), Schnabl (2012), Giannetti and Laeven (2012), Popov and Udell (2012), De Haas and van Horen (2012, 2013), Jeon, Olivero, and We (2013)) by analyzing the effect of monetary shocks transmission through foreign banks on credit supply and the real economy. Note that a large part of financial globalization occurs through banks (Kalemli-Ozcan, Papaioannou, and Peydro (2013)).
} 
the impact of U.S. and European QE/tapering and monetary policy rate tightening on emerging markets.

Our paper also contributes to the literature analyzing the risk-taking channel of monetary policy. Expansive monetary policy rates may promote higher risk-taking by banks and other financial institutions, as argued by IMF Chief Economist Raghuram Rajan (2005), Federal Reserve Governor Jeremy Stein (2013) and Adrian and Shin (2011), among others, and there is empirical evidence for this channel at the local level (e.g., Jiménez et al. (2014), Dell'Ariccia, Laeven and Suarez (2017)). ${ }^{9}$ We show that this channel is also present at the international level (Rey (2013), Miranda-Agrippino and Rey (2015), Bruno and Shin (2015a, 2015b)), in particular, that low monetary policy rates and QE in high-income countries lead global banks to increase the supply of credit in emerging markets to reach for higher ex-ante yield, and as a result observe higher ex-post loan defaults.

Finally, we contribute to the recent literature on the credit channel of monetary policy that analyzes the impact of monetary policy at the loan level (e.g., Jiménez et al. $(2012,2014)$ ) by showing the real effects associated to credit availability. Since these loan-level papers do not match their credit register data with firm level data, they cannot analyze the real effects. Nevertheless, real effects of monetary policy through the banking sector may be crucial, as shown by recent theoretical papers (Diamond and Rajan (2006), Gertler and Kiyotaki (2010), Kiyotaki and Moore (2012), Gertler and Karadi (2011)). Some empirical papers using aggregate macro data have analyzed the real effects of monetary policy (Bernanke and Blinder (1992)), but as we explain in this paper, matched loan level data is necessary for the identification of credit supply and real effects. Banklevel data (e.g., as in Kashyap and Stein (2000)) cannot identify credit supply, or firm-level real effects. Hence, another contribution of our paper is to show the real effects of the bank lending channel of monetary policy. ${ }^{10}$

\footnotetext{
${ }^{9}$ See also Altunbas, Gambacorta, and Marques (2014) and Paligorova Santos (2017) as well as the models of Allen and Gale (2000, 2004) summarized in Allen and Rogoff (2011), Borio and Zhu (2008), Shleifer and Vishny (2010), Diamond and Rajan (2012) and Cuadra and Nuguer (2016). Expansive monetary policy by increasing the funding provided by households and other agents to banks may increase risk-taking, as banks face strong moral hazard problems. A low short-term interest rate makes riskless assets less attractive and may lead to a reach-for-yield by those financial intermediaries that have short-term horizons. Ioannidou, Ongena, and Peydro (2015) analyze risk-taking on loans over four years in Bolivia (with a dollarized credit market) but do not analyze foreign banks or real effects due to credit.

${ }^{10}$ Loan-level data are crucial to identify credit supply (and risk-taking), especially as, for example, foreign banks may lend to different type of firms, and matched firm-credit-level data are needed to measure the real effects of credit at the firm level, differentiating firms by the extent to which they are affected by foreign banks. Additionally, our paper contributes to the literature by analyzing the lagged transmission of monetary policy on loan and firm outcomes, and by
} 
The remainder of the paper is structured as follows. Section I summarizes the empirical strategy, including the data and institutional details. Section II presents the results, and Section III concludes.

\section{Empirical Strategy}

In this section, we discuss the data and institutional details, along with empirical identification, and the econometric tests that we run at the loan, firm, and bank levels. In our empirical analysis, we use three main data sets. The first data set contains monthly supervisory information on commercial bank lending at the loan level. The second data set contains annual balance sheet and income statement information at the firm level from nonfinancial firms. The third main data set contains supervisory aggregate monthly information at the bank level, including balance sheet and income statements. Overall, the supervisory monthly data sets span from June 2001 to December 2015, while the annual data set runs through 2014. We also use macroeconomic information, including local and international monetary policy variables.

The first data set, at the loan level, uses supervisory information on the universe of business loans. The data come from reports sent monthly by each commercial bank to the regulator. Reports are mandatory, updated electronically, and include detailed characteristics on all new and continuing loans extended to firms by each bank in Mexico. Notably, all business loans, must be reported regardless of their size. Thus for each loan, we know the issuing bank, the borrower (firm), the outstanding balance, the (annualized) interest rate, the start and ending dates of the loan (maturity), the fraction covered by collateral, as well as certain firm details, such as its location and industry. Since loans are tracked each month, we can observe their evolution until maturity, including whether the debtor obligations are being fulfilled, and if they are not, for how long the loan has been underperforming and by how much. To ensure consistency of the data and to examine real effects associated with credit, we exclude from our study loans to individuals pursuing entrepreneurial activity, which restricts our analysis to loans to commercial firms, as the data we use to study real effects on firms has balance sheet information only for commercial firms, not for individual entrepreneurs.

analyzing the effect of monetary policy on loan rates (our results are consistent with theoretical literature that argues that banks may adjust lending volumes more than rates; see Stiglitz and Weiss (1981) and the literature following this paper). 
We aggregate observations at the firm-bank-month level, which results in 8,268,794 observations that we refer to as "loans". ${ }^{11}$ For the vast majority of variables, we aggregate individual loans using a weighted average by loan volume; the only exception is loan volume, which is the sum of all outstanding loans that a firm has from a certain bank in a given month. Table 1 presents summary statistics for our main variables of interest. The average credit volume is MXN 2,244,000 (roughly USD 172,000), while the median loan is close to USD 30,000. The median loan interest rate and maturity are $15 \%$ and 36 months, respectively. The average collateral value is $26 \%$, while the average default rate (which following prior literature corresponds to the fraction of loans that are in arrears for more than 90 days) is $7 \%$. See Table AI in the Appendix for the detailed definitions of all variables used in the paper.

\section{[TABLE I AROUND HERE]}

The macroeconomic and policy variables used in our empirical analysis are also summarized in Table I and in Figure 1. The Mexican monetary policy rate used is the Tasa de Interés Interbancaria a 1 Día (variable intrate-mex), while the U.S., U.K., and Eurozone policy rates are the Fed Funds rate (intrate-us), the SONIA rate (intrate-uk), and the EONIA rate, respectively (intrate-euro). Given that the Mexican economy is a small open economy that is highly affected by the U.S. economy, we run an OLS regression of the Mexican overnight interest rate on Mexican annual real GDP growth and CPI inflation, as well as on the Federal Funds rate and U.S. annual real GDP growth and CPI inflation, and use the residuals (intrate-mexr) in our benchmark regressions to isolate movements in the domestic monetary policy that are not explained by movements in the Mexican or U.S. economic activity. Similarly, we regress the overnight rates of the foreign central banks - U.S., Eurozone, and U.K. - on their respective annual real GDP growth and CPI inflation. For example, the variable intrate-usr is the residual from the regression of the Fed Funds rate on U.S. annual real GDP growth and CPI inflation, proxying for a Taylor shock, and accounts for any movement in the monetary policy from the U.S. that is not related to the U.S. business cycle. Given the synchronization of the world economy, one possible concern is multicollinearity of monetary

\footnotetext{
${ }^{11}$ To ensure the comparability of our results across banks, and given our focus on corporate lending, we exclude from our analysis banks that specialize in consumer lending as well as niche banking. These banks comprise less than $3 \%$ of the value of total corporate bank lending and less than $1 \%$ of the number of corporate loans. Around $97 \%$ of the number of loans in our data are denominated in Mexican pesos. We restrict our analysis to loans in domestic currency. Including loans in foreign currency does not alter our results in any significant way.
} 
policies. However, as can be seen in Figure 1, since we are controlling for the business cycles, the correlations between the residual monetary policies are relatively moderate. ${ }^{12}$

\section{[FIGURE 1 AROUND HERE]}

After the Lehman failure, U.S. and European overnight interest rates went to very low levels, especially in 2009. Central banks therefore engaged in various nonstandard policies such as largescale asset purchases and unlimited lending to banks with the objective of stimulating the economy. In our analysis, we explore all of these nonstandard policies across the core central banks using the variables qe-us, qe-uk, and qe-euro, which are the annual real change in the balance sheet of the respective central bank as a share of GDP. All three central banks increased sharply their asset holdings in the third quarter of 2008 , by around $8 \%$ to $10 \%$ of GDP. Going forward, however, these programs exhibited different purchasing patterns (see Figure 1 and Table I) which are important for identification. In particular, while the Federal Reserve, and to a lesser extent the Bank of England (BoE), maintained their purchasing rate for a full year through the third quarter of 2009, the ECB decreased its buying rate sharply by early 2009. In the second half of 2010, the Federal Reserve boosted its program (dubbed QE2), while the BoE and ECB only started to increase their purchasing programs in the second half of 2011 (the ECB introduced its three-year long-term refinancing operation (LTRO) in December 2011). Since 2013 there has been further divergence between central banks. For example, while the Fed pursued tapering, reduction in asset purchases, the ECB started its target LTRO program and QE. Overall, since the start of the financial crisis, the Fed, the $\mathrm{ECB}$, and the BoE expanded their balance sheet as a share of GDP by an average of 15 percentage points, but with significant differences in intensity and direction over time.

Table I also presents summary statistics of dummy variables indicating whether the loan is from a Mexican, U.S., U.K., or Eurozone owned bank (bank-mex, bank-us, bank-uk, and bank-euro, respectively). As can be seen, 39\% of loans are from Mexican banks, followed by Eurozone banks, at $32 \%$ of loans, U.S. banks at $15 \%$ and U.K. banks at $13 \%$ of the loans.

\footnotetext{
${ }^{12}$ For example, the correlation between intrate-usr and intrate-euro is 0.38 . Moreover, the correlations up to mid-2009, when policy rates hit the zero-lower bound, are around 0.15 . As a robustness test, in Table IA VII of the Internet Appendix we replicate our results using that subsample. In addition, we analyze QE measures (described below) cleaned by economic activity, and we run a specification using the residual of an OLS regression of the Mexican overnight interest rate only on the Mexican macro variables. The results are qualitatively similar. The Internet Appendix is available in the online version of the article on the Journal of Finance website.
} 
The second main data set that we use, Orbis, contains annual information on the balance sheet and income statement information. We use these data to examine whether movements in foreign monetary policy have real effects on firms. To do so, we aggregate the credit data to one observation per firm-year. Table I presents summary statistics of the firm-year level data set. The variable, loan volume ${ }^{Y}$, is the sum of all outstanding bank loans that a firm has in a given year across banks, and loan maturity ${ }^{Y}$ is the average maturity of all bank loans that a firm has in a given year weighted by loan volume. Similarly, the variables loan collateral $^{Y}$, loan rate $^{Y}$, and loan default ${ }^{Y}$ correspond to the weighted averages of the collateral, interest, and default rates of all bank loans that a firm has in a given year, again weighted by their respective loan volume. Finally, exit ${ }^{Y}$ is an indicator variable that takes the value of one if a firm with a loan in default drops from the loanlevel data set in a given year until the end of the sample and thus proxies for firm closure. Combining the credit data with Orbis results in a significant loss of observations, since for many firms the observation in Orbis is missing. Nevertheless, we successfully match around 14,563 firmyear observations with information on firms' total assets, fixed assets (whose variation provides net investment), and total employment, as well as firms' total, current, and noncurrent liabilities which allows us to check for other sources of firm finance. The vast majority of firms in Orbis, around 98\%, are non-listed firms. Using the employment information from the loan-level data, we find that the Orbis sample is not very different from the universe of firms (see Table IA V in the Internet Appendix), although it is biased towards larger firms. ${ }^{13}$ Moreover, as we show in Table IA XIX in the Internet Appendix, the results on real effects are stronger for smaller firms. Our results based on firm balance sheet information can thus be thought of as lower-bound estimates of the real effects of the average firm in Mexico.

To identify real effects at the firm level, we aggregate information at the firm-year level. Accordingly, we weigh the monetary policy (both standard and nonstandard) of each country by the share of loans that a firm had with banks from the country in the previous year. The intuition is as follows. If a firm borrows only from one bank (say a U.K. bank), then the most relevant monetary policy for the firm outcomes due to the bank lending channel should be the U.K. monetary policy. To see this, assume that in the previous year $40 \%$ of a firm's debt came from U.K. banks and $60 \%$ from Mexican banks. If firm-bank relations are persistent, which in our data set they are, then the

\footnotetext{
${ }^{13}$ The Internet Appendix is available in the online version of this article on the Journal of Finance website.
} 
most relevant monetary policies for this firm are those from the U.K. (with a 0.4 weight) and Mexico (with a 0.6 weight). ${ }^{14}$

For each firm, the variable intrate ${ }^{Y}$-mexr ${ }^{*}$ share $^{Y}$-mex refers to the annual Mexican monetary policy times the share of bank credit that a firm had with Mexican banks in the previous year. Similarly, the variable intrate ${ }^{Y}-$ fgn $^{*}$ share $^{Y}-f g n$ is the annual average of the U.S., U.K., and Eurozone monetary policy rates, weighted by the share of debt that a firm had with U.S., U.K., and Eurozone banks, respectively, times the share of foreign loans in the previous year. These aggregate monetary policy variables allow us to investigate whether firms with higher shares of credit from banks of a particular country are more vulnerable to changes in the monetary policy of that country. If firms could switch banks at no cost, then their past banking relationships should not impact their current or future real activity following a particular monetary policy shock, since they could smooth the shock by switching to other banks or by switching to other sources of financing. However, if switching banks is costly, then the effect of, say, a U.K. monetary policy shock (through U.K. banks) can have real effects on outcomes of Mexican firms that are dependent on U.K. banks.

Our third main data set contains monthly aggregate information on banks' financial statements including balance sheets, and income statements. We use these data to analyze the banks providing commercial loans, to control for their characteristics, and to test how different sources of bank funding are affected by international monetary policy shocks. The banking system has been dominated by five large banks that comprise $72 \%$ of total bank assets, a pattern that in most countries. Four of these banks are foreign-owned subsidiaries of major international banks from the U.S., U.K., and the Eurozone, with one, one, and two banks respectively. The remaining banks are mostly domestic and represent a heterogeneous group that focuses on different segments, such as corporate and consumer lending as well as niche banking.

Table IAII in the Internet Appendix presents summary statistics for all the commercial banks in our sample. The top half of the panel displays the results for common bank measures such as total assets, liquidity, and capital ratios as well as return on assets, while the bottom half shows the

\footnotetext{
${ }^{14}$ We find that bank-firm relationships are indeed sticky, with only $9 \%$ of firms switching their main bank from one year to the next. Furthermore, persistence in bank-firm relations does not differ across foreign and domestic banks (see Table IA VI in the Internet Appendix). Regarding the switching determinants, we find that switching rates are positively related to firm size and to the number of banks that the firm has relationships with, and negatively related to a loan's duration and volume. Somewhat surprisingly, if we define small (large) firms as those with fewer (more) than 50 employees (as Beck and Demirguc-Kunt (2006)), we find that the switching rates are somewhat similar at $8 \%$ and $11 \%$, respectively.
} 
fraction of commercial loans in each sector. The Mexican banking system as a whole is profitable, liquid, and well capitalized, with average return on assets of $1.0 \%$ and average return on equity of $12.9 \%$ over the period 2001 to 2015 . For comparison, during the same period the average return on assets for U.S. banks was $1.0 \%$ while their average return on equity was $10.4 \%$. The remaining columns of the table present the statistics for the largest five banks, divided by the country of their parent bank. As highlighted in the table, relative to the largest foreign banks, the characteristics of the largest Mexican bank are comparable. We note that our results go through if we only analyze the five largest banks in Mexico (see for example Table IAXIII in the Internet Appendix).

Apart from the banking sector, capital markets in Mexico are very small and used exclusively by the largest corporations (see for example IMF (2012), Carabarin, de la Garza, and Moreno (2016)). Shadow banking has grown as an alternative form of financing for firms over the last decade, albeit from a very low base. As of 2014, the assets from the shadow-banking sector, defined as financial entities not subject to traditional banking regulation, represented $16 \%$ of Mexico's GDP, compared to 42\% for the banking industry (Banco de Mexico, 2014). Therefore, even though Mexico is a bank-dominated economy, we also analyze the extent to which firms substitute with other sources of liabilities, in particular, total firm liabilities, as well as current and non-current liabilities.

Finally, to shed light on whether banks engage in reach-for-yield as monetary policies become more expansive, we split our sample into two groups based on the (ex-ante) loan rates that firms paid in the previous quarter. More specifically, each period we calculate the average loan interest rate charged to all Mexican firms, weighted by loan volume. We then classify firms above (below) this threshold as high-yield (low-yield) firms. The loan characteristics of these two groups are reported in Table IAIII in the Internet Appendix. As can be seen, low-yield firms pay lower interest rates (by definition) and have substantially higher collateral rates and lower default rates compared to high-yield firms, which suggests that they are indeed less risky.

As discussed earlier, we use regressions at the loan-month level (more specifically, firmbank-month level) to identify changes in firms' credit margins, and regressions at the firm-year level to examine changes in firms' real effects and credit substitution. Below we discuss the loan-level tests. We then discuss our firm-level tests.

\section{A. Outcomes at the loan level}


Our main objective is to understand whether foreign monetary policy shocks are transmitted to local firms through banks from the countries in which the shocks occur (e.g., Eurozone monetary policy transmitted by Eurozone banks in Mexico through their lending to Mexican firms). To do so, we investigate whether credit availability of a given bank is particularly affected by changes in the monetary policy of the country in which the bank is headquartered. As borrowers from different banks can be different, we need to analyze firm-bank-month data for identification.

Our baseline specification is given by equation (1) which is an OLS regression that relates the credit outcome of each firm-bank pair in a given month to the quarterly lagged monetary policies (both traditional and non-standard monetary policies) of each of the four countries considered. Each monetary policy is also interacted with an indicator variable that equals one if the bank providing the loan is headquartered in the given country and zero otherwise. For example, a loan given by a U.K. bank will have the value of zero for all of the dummies except that for U.K. monetary policy. The baseline specification is as follows:

$$
\begin{aligned}
& y_{i, b, t}=\rho+\sum_{\text {country }}\left[\alpha_{\text {country }} \text { intrate-country }_{t-3}+\beta_{\text {country }} \text { intrate-country }_{t-3}{ }^{*} \text { bank-country }_{b}\right]+ \\
&+\sum_{\text {country }}\left[\gamma_{\text {country }} q e\right. \text {-country } \\
& t-3
\end{aligned}
$$

In equation (1), $y_{i, b, t}$ corresponds to the credit outcome $y$ of firm $i$ that has a loan with bank $b$ in month $t$, where credit outcome $y$ is one of $\log (\operatorname{loan}$ volume), $\log$ (loan maturity), collateral rate, loan rate, or the fraction of loans in default 12 months ahead. ${ }^{15}$ The regressor intrate-country $y_{i, t-3}$ is the one-quarter-lagged monetary policy rate of country $=\{U . S ., U . K .$, Euro, Mex $\}$, bank-country is a bank nationality's indicator. ${ }^{16}$ The regressor $q e$-country $y_{i, t-3}$ measures the annual real change in the balance sheet of the central bank (over its GDP) of a country in the previous quarter $(t-3)$. Moreover,

\footnotetext{
${ }^{15}$ For robustness, we also tested for the fraction of loans in default six and 24 months ahead. The main results continue to hold in all specifications.

${ }^{16}$ In our analysis, we use the residuals of the regression of monetary policy on macro movements intrate-countryr instead of intrate-country to isolate monetary policy shocks from changes in rates due to business cycle movements. More specifically, to calculate intrate-mexr, we use the residuals of the regression of intrate-mex on Mexican and U.S. annual real GDP growth and CPI inflation, as well as on intrate-us. For the remaining countries we use the residuals of the regression of intrate-country on country annual real GDP growth and CPI inflation. For simplicity, the residuals of the monetary policy regressions described above are referred to as "monetary policy rates" in the empirical strategy and results sections. We also use lags of monetary policy other than one quarter. Specifically, in robustness tests, instead of using the monetary policies with one-quarter lag, we ran specification (1) using alternative monetary policies with lags up to 24 months. We find that up to 12 months, all of these tests yield qualitatively similar results. After 12 to 15 months, the coefficients start to become statistically indistinguishable from zero.
} 
additional controls included in $X_{b, t}$ are the one-quarter lagged annual growth rates of all countries' GDPs and CPIs (all in levels and interacted with the indicator variables of banks' nationalities) as well as sovereign CDS. These variables allow us to control for the business cycles, and to better isolate changes in monetary policy from other changes in economic activity. ${ }^{17}$

Equation (1) also includes several fixed effects. A key challenge of our empirical strategy is that different banks may have borrowers with different characteristics, complicating the identification of the (international) bank lending (supply) channel of monetary policy. To achieve identification, we first saturate our loan-level specification with fixed effects at the firm*bank level. ${ }^{18}$ This allows us to exploit the variation within the same firm and bank over time. This not only controls for unobserved, time-invariant, firm heterogeneity (industry, location, ownership) and bank heterogeneity, but also for sticky firm-bank relationships. Our identification comes from the fact that within a period, banks from different nationalities may be differently affected by the monetary policy shocks of their respective countries.

We also include in some specifications firm*month fixed effects. By doing so, we examine whether for a given firm in a given month, the loans offered by different banks depend on the monetary policy shocks of their parent countries. In this case, we control exhaustively for unobserved time-varying firm fundamentals (such as firm risk, investment opportunities and balance sheet characteristics). One drawback of the specifications that include firm*month fixed effects is that they restrict the sample to firms that at a given point in time have loans with more than one bank. These firms represent only $21 \%$ of the sample firms, and together hold $37 \%$ of the loans. This exercise could therefore bias our results since these firms tend to be larger and older. Accordingly, in some specifications instead of using firm*month fixed effects, we use state*industry*month fixed effects to proxy for demand shocks. However, in order to determine whether differences across specifications are due to unobservables or to the sample selection of firms, we run the latter specification twice: first using all of the firms in our data, and then using only firms with multiple bank relationships.

\footnotetext{
${ }^{17}$ When we saturate the regressions with different sets of time fixed effects to control for time-varying unobservable heterogeneity in fundamentals, the macro controls are spanned by these fixed effects (including all unobserved timevarying bank fundamentals). In addition to controlling for global shocks via month fixed effects, we control for foreign economic activity in interactions with our main variables, as this could be a separate channel of influence.

${ }^{18}$ Importantly, note that identification is not possible with just bank - or firm-level data, as different banks may lend to different types of firms. For example, foreign banks could lend to firms that tend to export more.
} 
As further robustness checks, we test the validity of the bank-lending channel by analyzing the effect of foreign monetary policy on different subsamples of firms, such as firms in more tradeable versus less tradeable sectors, (e.g. Mian and Sufi (2014)), and firms located in northern versus southern states, see Tables IAIX and IAX of the Internet Appendix. Note that period fixed effects control for unobserved global shocks, and hence identification also comes in a particular period from the differential monetary policies among Mexico, the U.S., the U.K., and the Eurozone. Since our identification further compares lending from different foreign banks (themselves shocked by their home monetary policy), it follows that borrower selection is less of an issue. ${ }^{19}$ Note that time fixed effects imply that we identify how foreign monetary policies affect foreign versus domestic banks in lending to a given firm (or industry-location) in a given month. Finally, to identify the risk-taking channel of monetary policy, we test equation (1) on firms with high versus low ex-ante loan yield and analyze all credit outcomes, including (ex-post) loan defaults.

\section{B. Outcomes at the Firm Level}

While monetary policy shocks may be passed to firms through the bank lending channel, the real impact on firms may not be substantial if, for instance, firms can smooth the shocks by switching banks, or by replacing bank credit with other sources of finance, such as market debt, including finance from the shadow banking sector. Therefore, to analyze real effects, we need to examine firm-level data (matched with credit data to differentiate firms across their dependence on foreign banks and hence on monetary policy). The specification that we use for the effect of monetary policy shocks on firm credit and for other real effects is as follows:

$$
\begin{aligned}
& y_{i, t}{ }^{Y}=\theta+\lambda_{\text {mex }} \text { intrate }^{Y} \text {-mexr }{ }_{t}{ }^{*} \text { share }^{Y} \text {-mex } \text { i,t-1 }_{1}+\lambda_{\text {foreign }} \sum_{\text {country }} \text { intrate }^{Y} \text {-country }{ }_{t}{ }^{*} \text { share }^{Y} \text {-country } y_{i, t-1} \\
& +\mu_{\text {foreign }} \sum_{\text {country }} q e^{Y} \text { - country }{ }_{\mathrm{t}} \text { share }^{Y} \text { - } \text { country }_{\mathrm{i}, \mathrm{t}-1}+\epsilon_{\mathrm{i}, \mathrm{t}} .
\end{aligned}
$$

The dependent variable $y^{Y}$ corresponds to: (i) the bank-credit outcomes aggregated at the firm-year level (loan volume $e^{Y}$ and loan maturity ${ }^{Y}$ in logs, loan collateral $^{Y}$, loan rate $^{Y}$, and loan

\footnotetext{
${ }^{19}$ For instance, we find that within the largest banks, borrowers are not statistically different. Using loan and firm level information, we find that across the largest banks (which include one domestic bank as well as banks from the U.S., the U.K., and the Euro Area), borrowers have similar characteristics in terms of their bank credit volume and total assets (see Table IAIV of the Internet Appendix) and, therefore, conditional on borrowing from the largest banks, firms with loans from U.S., Eurozone, or U.K. banks are not statistically different from each other or from firms with loans from the largest Mexican bank. Interestingly, we also confirm that our main results hold for firms only borrowing from large banks, whether foreign or Mexican (see Table IAXIII in the Internet Appendix).
} 
default $^{Y}$ ), (ii) an indicator for whether a firm with loan defaults shuts down in a given year $\left(\right.$ exit $\left.^{Y}\right)$, (iii) firm total, current, and long-term liabilities (liabilities ${ }^{Y}$, current liabilities $^{Y}$ and noncurrent liabilities ${ }^{Y}$ ), and (iv) firm total assets $\left(\operatorname{assets}^{Y}\right.$ ), fixed assets (fixed assets ${ }^{Y}$ whose variation proxies for net investment), and employment (employment ${ }^{Y}$ ). The last six variables (from Orbis) are in logs and only available at the annual frequency, and thus the main regressions at the firm level are at the firm-year level (however, and to facilitate comparison purposes with the variables at the loan level we also run the regressions at the monthly level for bank credit related variables).

The first covariate, intrate ${ }^{Y}$ country $_{i, t}{ }^{*}$ share $^{Y}$ - country $_{i, t-1}$, refers to the average monetary policy rate of country $=\{$ U.S., U.K., Euro, Mex $\}$ in year $t$ times the share of the previous year's bank loans that a firm had with banks headquartered in a given country (see the previous subsection and Appendix Tables AI and AII for variables' definitions). Similarly, q $e^{Y}$-country ${ }_{i, t}{ }^{*}$ share $^{Y}$ country $_{i, t-1}$ corresponds to the annual average QE of country $=\{U . S .$, U.K., Euro $\}$ times the oneyear-lagged share of a firm's loans with a bank from that country. Given our interest in contrasting foreign versus domestic banks, we aggregate the foreign monetary policies (weighting each foreign policy by the lagged share of loans that a firm has with banks from each foreign country), using intrate $^{Y}-$ fgnr $_{i, t}{ }^{*}$ share $^{Y}-f g n_{i, t-1}$, and $q e^{Y}-f g n_{i, t}{ }^{*} \operatorname{share}^{Y}-f g n_{i, t-1}$, and we calculate two coefficients $\left(\lambda_{\text {mex }}\right.$, $\left.\lambda_{\text {foreign }}\right)$ for the monetary policy rates and one coefficient $\left(\mu_{\text {foreign }}\right)$ for $\mathrm{QE}$.

In contrast to specification (1), on the left-hand side of (2) we analyze all bank credit to a firm in a given year. The right-hand side of this specification consists of a measure of firm-level exposure to each monetary policy shock that is based on previous bank relationships. Given that banking relationships are sticky over time (see Table IAVI of the Internet Appendix for our Mexican data and Ongena and Smith (2001) for other countries), the assumption behind this specification is that the intensity of the monetary policy shock of a particular country is proxied by the previous year's share of a firm's debt with banks from that country.

Finally, we saturate our specification with fixed effects at the firm level which allows us to control for time-invariant unobserved firm heterogeneity (such as location), and at the state*industry*year level, which allows us to control for time varying borrower fundamentals (and exploit the variation across loans from different banks to the same industry, in the same location and the same period). Importantly, as we discuss in Section II, following Altonji, Elder, and Taber (2005), the loan level regressions show that controlling for firm*period fixed effects provides similar coefficients to controlling only for firm and state*industry*period fixed effects (i.e., results 
suggest that both specifications similarly control for borrower fundamentals). Therefore, the firmlevel regressions, where we cannot include firm*year fixed effects, but we can include firm and state*industry*year fixed effects, can be interpreted as identifying the credit availability channel.

In sum, in equation (2) we investigate whether firms are able to smooth monetary policy shocks of a foreign country by switching banks or by switching to other sources of finance. If firms can easily switch banks to smooth shocks, the coefficients $\lambda_{\text {foreign }}$ and $\mu_{\text {foreign }}$ should not be statistically different from zero. Thus, this equation tests whether a monetary policy shock for the country of origin of the firm's previous banks influences the firm's overall bank credit in the current year. If changing banks is relatively easy, previous bank relationships should not be important and monetary policy shocks should have little real effect on a firm.

Since we also analyze firms' total (current and noncurrent) liabilities, we can ensure whether firms replace bank credit with other types of debt, or whether foreign monetary policy shocks that are passed through the bank lending channel have a binding effect on firms' overall liabilities. In the latter case, the coefficients $\lambda_{\text {foreign }}$ and $\mu_{\text {foreign }}$ on liabilities ${ }^{Y}$, noncurrent liabilities ${ }^{Y}$, and current liabilities ${ }^{Y}$ should be statistically different from zero. Finally, if bank credit and overall liabilities are affected, real effects stemming from foreign monetary shocks are likely to exist. We test for this possibility by looking at the change in firms' total assets and employment as well as firm net investment (variation of fixed assets). ${ }^{20}$

\section{Results}

This section presents our findings. We use data at the borrower-lender-month (loan) level to analyze the effects of foreign monetary policy on banks' credit supply and risk-taking. To study the associated real effects and credit substitution, we use data at the firm-year level.

\section{A. Loan-Level Credit Supply Outcomes}

\footnotetext{
${ }^{20}$ We further analyze bank-level data at the monthly frequency to see whether our findings also hold at a more aggregate level, and to better understand the mechanism underlying our results. Using this data set, we examine the sensitivity of the total bank assets, the various bank liability measures and share of credit in arrears of foreign and domestic banks to movements in monetary policies. The results are presented in Table IAVIII in the Internet Appendix, where the regressors are: intrate-fgnr*bank-fgn, which is the one-quarter lagged foreign monetary policy rate residual times an indicator variable that equals one if the bank is foreign; intrate-mexr*bank-mex, the one-quarter lagged residual of the Mexican policy rate times an indicator variable that equals one if the bank is headquartered in Mexico; and qe-fgn*bank$f g n$, which is the one-quarter-lagged annual change in the balance sheet of the corresponding central bank over GDP times an indicator variable that equals one if the bank is of foreign origin. We also include macro controls, namely, annual GDP and CPI growth, a linear trend for each country/region where banks are headquartered (to allow for different growth rates of the regions examined), and period and bank fixed effects.
} 
Panel A of Table II presents results on the effect of the various foreign monetary policies on the volume of loans to firms in Mexico. The first column reports results of the baseline specification outlined in equation (1) controlling for fixed effects at the firm*bank level. As the results show, the three different foreign monetary policy rates have stronger effects on credit outcomes of banks from the same country. That is, U.S., U.K., and Eurozone policy has greater effects on lending in Mexico via U.S., U.K., and Eurozone banks respectively. ${ }^{21}$ As for the nonstandard monetary policies, QE of the U.S., the U.K., and the Eurozone affects more the credit volume of firms whose loans are from U.S., U.K., or Eurozone banks respectively. In contrast, the Mexican policy rate affects the credit volume of all banks, regardless of their nationality. In other words, the overnight rate set by the Bank of Mexico affects banks operating in Mexico irrespective of whether they are Mexican. This may be because similar to domestically owned banks, foreign subsidiaries in Mexico have substantial local retail deposits and are therefore also affected by local monetary policy (see Table IAII in the Internet Appendix).

\section{[TABLE II PANEL A AROUND HERE]}

To further control for time-varying unobserved borrower characteristics, in column (2) we saturate equation (1) with state*industry*period in addition to firm*bank fixed effects. The results from columns (1) and (2) suggest that even after controlling for these proxies for credit demand, the coefficients on monetary policy remain statistically and economically significant. As mentioned above, variation in a foreign monetary policy rate affects substantially more the banks from that origin. For example, focusing on column (2), a one-standard-deviation decrease in the Fed Funds rate raises the average loan volume of U.S. banks in Mexico by 6\%, and a one-standard-deviation decrease in the monetary policy rate from the U.K. (Eurozone) expands credit by $4.8 \%$ (2\%) on average. ${ }^{22}$ It is important to stress that the coefficients in column (2) are better identified than those in column (1) as in addition to firm*bank fixed effects, we control for time-varying firm fundamental heterogeneity via state*industry*period fixed effects.

\footnotetext{
${ }^{21}$ Despite the numerous time-varying controls and the exogeneity of foreign monetary policy, Table A12 provides an additional robustness check of the exogeneity of the U.S. monetary policy. In that table, we instrument the Fed Funds rate (following the instruments suggested in Gertler and Karadi (2015)) for the period June 2001-November 2009, which corresponds to the period in which the Fed Funds rate had not reached the zero lower bound. The results using the instrument of the U.S. policy rate are consistent with our findings. We thank Mark Gertler and Peter Karadi for sharing their data.

${ }^{22}$ Note that the standard deviations of interest rates and also of QE differ across countries (see Table I).
} 
While the effect of QE on the supply of credit is not trivial, it is lower than that of standard monetary policy rates. For example, a one-standard-deviation expansion in the assets held by the Federal Reserve (relative to U.S. GDP) increases the volume of loans from U.S. banks by $2.6 \%$. Similarly, a one-standard-deviation increase in the BoE's assets expands credit by $2.1 \%$. In contrast, the $\mathrm{QE}$ of the Eurozone becomes statistically insignificant once we control for time-varying unobservables at the state and industry levels. This result highlights the fact that analyzing creditsupply outcomes with only bank-level data would be misleading as lenders are not matched exogenously with borrowers. ${ }^{23}$

In column (4) we saturate equation (1) with firm*month fixed effects (in addition to firm*bank effects) and focus on variation across loans offered by different banks to a given firm in a given month. However, this specification requires that firms hold loans from multiple banks in the same month, and such firms tend to be larger and, hence, may be differently affected by monetary policy shocks. Not surprisingly, we lose more than half of the observations and some coefficients lose statistical significance. To examine whether our coefficients change due to the sample selection, in column (3) we use the same specification as in column (2), but we restrict the sample to firms that in a given period have loans with more than one bank. As column (3) indicates, the coefficients that drop by half in column (4) do so because of the selection bias towards larger firms. Importantly, note that in column (4) the estimated coefficients are not statistically different from those of column (3) despite a substantial increase in the $\mathrm{R}^{2}$ (around 43 percentage points). This suggests that our main coefficients on credit supply shocks (foreign banks and monetary policy) are exogenous to unobserved demand proxied by (firm*month) time-varying firm unobservables and observables (following Altonji, Elder, and Taber (2005)).

Panel B of Table II reports results on the effects of changes in monetary policies on the three other margins of loans - maturity, collateral, and interest rate - as well as future loan defaults. On average, a one-standard-deviation reduction in foreign monetary policy translates into loans that are not only larger, but also of longer maturity, and for U.S. banks, into lower interest rates. ${ }^{24}$ While the supply of bank credit also increases with an expansion of foreign QE, its economic effect is lower

\footnotetext{
${ }^{23}$ However, we next show that monetary policy effects are stronger when the sovereign risk of the foreign country is lower, and hence the weak results of Eurozone banks in the crisis via QE reflects the higher financial risk. See also Table IAXIV in the Internet Appendix.

${ }^{24}$ Moreover, a softening of foreign monetary policy increases collateral by $5.7 \%$, which could be due to higher valuation of the collateralized assets when policy is softer. Our main results hold when we control for changes in collateral, that is, our results are robust to controlling for collateral as a right-hand-side variable (so even if collateral value is higher, the softening effects on the other loan outcomes are significant).
} 
and is concentrated on volume. Moreover, changes in U.S. QE have a larger effect than changes in U.K. or Eurozone QE, as it affects not only loan volume but also loan rate and maturity. More specifically, a one-standard-deviation increase in U.S. QE results in loans from U.S. banks that on average are $2.6 \%$ larger in volume, have $7.8 \%$ longer maturity, have no change on collateral, and have 0.3 percentage points lower interest rate.

\section{[TABLE II PANEL B AROUND HERE]}

Finally, in the last two columns we investigate if future loan defaults (the share of loans observed in default at $t+12$ months) are affected by the loosening of credit conditions in response to softer monetary policy. ${ }^{25}$ The results suggest that in general, softer monetary policies abroad (standard and nonstandard) lead to higher future loan default rates of banks from the same country or region. Moreover, and as we show later, softer monetary policy induces banks to lend relatively more to firms with higher risk as proxied by higher ex-ante loan rates, which also helps explain our result on defaults. ${ }^{26}$

Next, in Panel C, we analyze the sensitivity of changes in the various credit margins to the timing of the monetary policy. Here we classify banks as domestic or foreign, and we regress the different credit margins on different lags of foreign and domestic monetary policies (ranging from three to 24 months). Observations are still at the firm-bank-period level, but each firm has at most two observations per period depending on whether it has loans from domestic banks, foreign banks, or both. ${ }^{27}$

\section{[TABLE II PANEL C AROUND HERE]}

Our results suggest that, when the benchmark one-quarter-lagged foreign monetary policy rate declines by one standard-deviation, loans from foreign banks increase their volume by $1.5 \%$, lengthen their maturity by $4.8 \%$, and increase collateral values by $4.6 \%$. In addition, the impact of

\footnotetext{
${ }^{25}$ Our measure of future default for the firm-bank pair at time $t$ is the default rate of the firm-bank pair at $t+12$, or if the pair left our sample prior to $t+12$, the last observation available. In the empirical exercises involving the default rate at $t+12$ we only use data until December of 2014. In addition to $t+12$, we also studied the impact on default at $t+6$ and $t+24$. The results are qualitatively similar.

${ }^{26}$ As a robustness check, in Table IAXV in the Internet Appendix, we also analyzed asymmetric monetary policy effects. We do not find statistically different results. In particular, most of the coefficients on asymmetry are not significantly different from zero, though in a few cases, it may be due to lack of statistical power. One coefficient that is asymmetric is the impact of QE on loan defaults, which is entirely driven by the expansive monetary period.

${ }^{27}$ We construct the credit margins as follows. In each month, the loan volume that a firm obtains from foreign (domestic) banks is given as the sum of the outstanding loans that the firm has from all foreign (domestic) banks in the period. The other credit margins of loans from foreign (domestic) banks - maturity, collateral, and loan rate-as well as defaults correspond to their average weighted by loan volume.
} 
lagged foreign monetary policy on credit supply is somewhat persistent within a range of three to 12 months, and then declines after 12 months (not shown). The coefficients on loan volume, collateral, and interest rates coefficients achieve their maximum absolute value at 12-month lags, while maturity and the default rate are relatively less persistent. Regarding QE, the coefficients also increase at higher lags, especially for volume and defaults. Overall, for both types of monetary policy shocks, the speed of transmission becomes weaker after 12 to 15 months, and while there is some heterogeneity in the speed of transmission across loan margins in the first 12 months, the effects are generally stronger between six and 12 months for both monetary rates and QE.

A possible concern is that the results in Table II could be driven by the commercial characteristics of banks and not by the specificities of foreign monetary policies. To formally test for this possibility, we reestimate Panel A of Table II, controlling for time-varying bank characteristics (in addition to bank*firm fixed effects) such as bank total size, liquidity and capital ratio. The results are reported in Table IAXI in the Internet Appendix, and are not meaningfully affected by the introduction of these controls. Moreover, in Table IAXIII we find similar results when we estimate only the loans of the five largest banks (four foreign and one Mexican bank). Another concern is that the results may be driven by a subset of customers. For example, U.K. banks may be serving firms that export to the U.K. To control for this possibility, we rerun our regressions separately for exporters and non-exporters, where we classify firms by either (i) tradable versus nontradable industries, following Mian and Sufi (2014), or (ii) northern versus southern states, since the northern states in Mexico have substantially more economic relations with the U.S. (INEGI (2014)) as well as a larger share of exports to GDP (39\% compared to 12\%). The results are reported in Tables IAIX and IAX in the Internet Appendix, and show no difference between exporters and non-exporters with regard to the impact of foreign monetary policy on credit outcomes via foreign subsidiaries. This result is not surprising as the subsidiaries of foreign banks in Mexico are important across all sectors, as shown in Table IAII in the Internet Appendix.

Finally, we use bank-level data to test whether our loan-level results are also present at a more aggregate level, and to further understand the economic mechanisms behind our findings. The results are presented in Table IAVIII in the Internet Appendix. Columns (1) and (2) corroborate our loan-level results: when foreign monetary policy becomes more expansive, total assets and oneyear-ahead credit-in-arrears of foreign banks increase more. We find a similar pattern for changes in foreign QE. The next three columns provide insights into the economic mechanisms behind our 
results. Compared to domestic banks, foreign banks borrow substantially more, especially from abroad, when foreign monetary policy is softer. That is, compared to domestic banks, foreign banks obtain more funds from foreign markets when foreign monetary policy is softer. Furthermore, while not statistically significant, the economic magnitude of the coefficient capturing the effect of foreign monetary policy on short-term liabilities is very high (the coefficient is high and larger than on the other margins but with substantially higher standard errors), suggesting that foreign banks obtain more short-term funding when foreign monetary policy is softer.

Taken together, our results are consistent with foreign banks taking on more liquidity (partly from abroad) and credit risk (providing more credit and observing higher ex-post defaults), and despite the fact that their liabilities are more fragile (foreign and partially of shorter term), these banks lend at longer maturities on the asset side (with higher credit volume and to riskier borrowers, as suggested by the higher ex-post loan defaults, and as we will see in Section II.C, by lending to ex-ante riskier borrowers).

\section{B. Firm-Level Credit Supply Outcomes and Real Effects}

To examine whether monetary policy shocks have real effects on firms, we need to analyze firm-period-level data by matching the credit register to firm balance sheet data. This allows us to investigate whether, for example, the total credit that firms obtain is affected by changes in foreign monetary policies. Importantly, when we restrict the analysis in the loan-level regressions to firms that borrowed from at least two banks in a given period, the estimated effects of monetary policy remained relatively unchanged (see for example the comparison of columns (3) and (4) of Table II, Panel A). Therefore, firm and state*industry*period fixed effects in firm-level data provide sufficient controls for unobserved borrowers, which allows us to identify the bank credit supply channel at the firm level.

The first five columns of Table III present results of our bank credit outcomes for the firmyear-level data. We find that, on average, firms with a higher lagged share of bank credit from foreign banks are more affected by the monetary policy in these countries. For example, for firms whose total bank credit was with foreign banks in the previous year, a one-standard-deviation reduction in the intrate ${ }^{Y}-f g n$ in the current year leads to an increase in loan volume of $1.5 \%$, a rise in maturity and collateral of $4.9 \%$ and $4.8 \%$, respectively, and a decline of $0.8 \%$ in interest rate. With 
respect to loan default (delinquencies), a one-standard-deviation reduction in intrate ${ }^{Y}$-fgn increases loan default by $5.3 \%$. Finally, the impact of the average nonstandard monetary policy at the firmlevel is generally not statistically significant, except for collateral and default, but the lack of significance is due in part to higher standard errors.

\section{[TABLE III AROUND HERE]}

There are also significant real effects. On the extensive margin, a one-standard-deviation reduction in intrate $^{Y}-f g n$ reduces firm exit due to loan defaults by $1 \%$. The final six columns display the results for the intensive margin for firm-level variables obtained from Orbis. For total liabilities, assets, fixed-assets, and employment, we find that foreign monetary policy shocks have real effects on firms (columns (7) to (12)). For instance, total firm liabilities (including bank credit) increase by $1.2 \%$ when the average foreign monetary policy declines by one standard deviation in a given year, while fixed assets (i.e., net investment) rise by $0.5 \% .{ }^{28}$ Employment also increases, but by only $0.3 \%$. Note that, since with this data set we have only a few annual observations for each firm after the QE period started, our results for the impact of nonstandard monetary policies on real outcomes could lack statistical power (e.g. for loan outcomes, all QE results are statistically significant in the monthly level data). ${ }^{29}$ Moreover, we analyze whether the effect of the monetary policy depends on firm size. To do so, we reestimate equation (2) interacting the monetary policies with an indicator for small firms with fewer than 50 employees (following Beck and Demirguc-Kunt (2006)). The results are displayed in Table IAXIX in the Internet Appendix, and indicate that the effects are indeed stronger for smaller firms, while nonexistent for large firms. Therefore, given the somewhat overrepresentation of large firms in Orbis (see Table IAV in the Internet Appendix), our results for the firm balance sheet variables suggest a lower bound on the real effects.

A possible concern regarding the relatively subdued effect of QE on the majority of the results is that this unconventional policy is highly correlated with periods of high risk and uncertainty, such as those observed after the global financial crisis, in which case the results may be biased towards zero given the positive correlation between the QE measures and various measures

\footnotetext{
${ }^{28}$ We analyze net, not gross, investment, which is common in the literature. See for example Lang, Ofek, and Stulz (1996). If investment expenditures just match the depreciation of capital equipment, then gross investment rises, but net investment is unchanged. Higher net investment, not gross, is what matters for overall productivity, and it is computed as the annual change in fixed tangible assets. Note also that the effects are larger for bank credit than for total liabilities and assets (Table IAXVIII in the Internet Appendix shows that the results do not depend on the scale of the different firm variables).

${ }^{29}$ See Tables IAXVI and IAXVII in the Internet Appendix for different lags of monetary policy on firm outcomes.
} 
of financial risk. To test for this possibility, we interact our QE measure with the sovereign CDS of the country. The results, present in Table IAXIV in the Internet Appendix, show that the QE results are indeed stronger the lower is the CDS of the sovereign where the foreign bank is headquartered. This may explain why for some results, elasticities for QE are lower than those for interest rates, especially for the Eurozone banks given the Eurozone crisis. In sum, when the Federal Reserve, the ECB, and the BoE expand their balance sheet via nonstandard monetary policies, the U.S. and European banks expand into Mexico less, the higher is the risk in the countries where their parent banks are located.

\section{Reach-for-Yield and Risk-Taking Channel of Monetary Policy}

To further understand the risk-taking behavior of banks, and to determine whether they engage in ex-ante reach-for-yield, we examine whether credit terms are more likely to change for firms with higher ex-ante loan interest rates, which tend to have higher ex-post default rates (see Table IAIII in the Internet Appendix). To do so, in each period we calculate the average interest rate charged by banks to all firms (firm-bank observations weighted by loan volume). We then separate our sample into two groups depending on whether their ex-ante cost of credit is above or below this average cost, and rerun equation (1) separately for these two samples of firms. The results are presented in Table IV.

\section{[TABLE IV AROUND HERE]}

Results indicate that, on average, foreign banks soften lending conditions more to firms with a higher ex-ante interest rate when foreign monetary policy is relaxed. These effects operate in the same direction for the different lending margins and imply higher future loan defaults. In the first two columns of Table IV, we find that a one-standard-deviation decrease in foreign monetary policy increases loan volume for the high-yield group by $5 \%$ on average, and in the low-yield group by only $1.3 \%$. The effects are large for U.S., U.K., and Eurozone banks. Similarly, a one-standarddeviation increase in QE increases loan volume of high-yield firms by around $1.5 \%$ but has no statistically significant effect on the sample of low-yield firms. ${ }^{30}$

Loan maturity (which proxies for liquidity risk) is the credit margin through which highyield firms (which proxy for credit risk) benefit relatively more from an expansion in monetary

\footnotetext{
${ }^{30}$ For QE, effects are not significant for Eurozone banks, except for higher ex-post loan defaults. Note that these banks were more affected by higher CDSs of their sovereign, which mitigate the effect of QE on loan margins.
} 
policies. As columns (3) and (4) indicate, a one-standard-deviation reduction in the average foreign interest rate lengthens the average loan maturity by $10 \%$ for high-yield firms, whereas its effect is negligible among low-yield firms. We also find that on average foreign QE has a stronger, albeit smaller, effect on low-yield firms. In addition, while banks extend on average larger and longer loans to riskier firms when foreign monetary policy expands, the value of collateral requirements increases, possibly due to valuation effects (Columns (5) and (6)). Regarding loan rates, columns (7) and (8) show that in general, interest rates from high-yield firms respond in the direction of the changes to foreign monetary policy, whereas low-yield firms do not. On average, a one-standarddeviation reduction of foreign monetary policy translates into a $1.1 \%$ reduction in the average loan rate of high-yield firms. As with other credit margins, interest rates of loans are also influenced by changes in QE. Our results suggest that a one-standard-deviation increase in U.S. QE translates into a 0.3 percentage points reduction on the average loan rate on loans for high-yield firms.

Focusing on future default, in columns (9) and (10), we also find that the effect of a loosening of credit conditions on future default is concentrated among firms with high yield. In particular, default rates are more responsive to changes in monetary policy from the U.S. and the U.K. (both standard and nonstandard) and from the Eurozone (mainly nonstandard). For instance, a reduction of one standard deviation in the foreign interest rate increases the average default for highyield firms by $11.7 \%$ and has no significant impact for low-yield firms. Similarly, the expansion in QE increases the incidence of default. Changes in foreign QE are associated on average with an $8.6 \%$ increase in the share of bank credit in default among high-yield firms.

Taken together, the increase in credit supply due to low foreign monetary policy rates and expansive QE is stronger for borrowers with higher ex-ante loan rates, which proxy for reachingfor-yield, and with higher ex-post loan defaults, and thus suggests an international risk-taking channel of monetary policy. Quantitatively, these effects are large.

\section{Conclusions}

We analyze the international bank lending and risk-taking channel of monetary policy rates and QE through foreign banks. We analyze foreign banks, as in addition to being affected by their own country's monetary policy, these banks are important both around the world, and in emerging markets, where they account for approximately $50 \%$ of the market share. Despite the importance of 
these questions for both public policy (notably, central banking policies and international monetary and financial coordination) and academia (international macro-finance), identification of the international channel of monetary policy has not been possible due to the lack of comprehensive credit registry data matched with firm and bank information. As we stress in the introduction, the empirical literature on the international risk-taking and credit channel of monetary policy has mainly focused on macro- or bank-level data. We overcome this hurdle by analyzing the case of Mexico, an ideal empirical setting for identification given the exhaustive micro data sets (credit register matched to firm- and bank-level data) as well as given the important presence of foreign banks.

We use the supervisory data set that contains information on all business loans in Mexico, including interest rates, which are absent from most credit registers around the world, while exploiting foreign monetary policy shocks, both standard policy rate and nonstandard QE. Loanlevel data are crucial to identify credit supply (and risk-taking), as foreign banks may lend to different types of firms, and matched firm-credit level data are needed to measure the associated real effects of the credit channel of monetary policy.

Robust results suggest that a softening of foreign monetary policy increases the supply of credit of foreign banks to Mexican firms. Each regional policy shock mainly affects supply via the region's respective foreign banks. That is, U.S., U.K., and Eurozone monetary policy mainly affects credit supply to Mexican firms via U.S., U.K., and Eurozone banks in Mexico, respectively. All loan terms are affected, but effects are substantially weaker for loan rates. Moreover, the international monetary policy channel implies strong real effects, with much stronger elasticities on monetary rates than QE. Finally, low foreign monetary policy rates and an expansion in QE lead to higher credit supply by foreign banks for borrowers with higher ex-ante loan rates (reaching-for-yield), with substantially higher ex-post loan defaults, thus suggesting an international risk-taking channel of monetary policy.

In sum, the results suggest spillovers of core countries' monetary policies into emerging markets, both in the foreign monetary softening part (with not only higher credit risk taken by foreign banks, but also higher liquidity risk stemming from higher foreign funding) and in the tightening part (with the negative associated local real effects in terms of lower firm-level total assets, net investment, employment, and survival). 
Importantly, not only is foreign monetary policy key to analyzing the international channel and to obtaining exogenous variation of monetary policy, as compared to local policy, but it is not determined by local economic conditions of emerging markets. This implies that a change in foreign policy can be further destabilizing, especially given the foreign bank channel that we document in this paper. Indeed the results are consistent with some claims by, among others, Reserve Bank of India Governor Raghuram Rajan (2014) and Helene Rey (2013) on the effects of core countries' monetary policies on emerging markets' economies, and thus suggest a need for more coordinated global monetary policy, for example at the G-20 level with both high income and emerging countries, or the use of local prudential policies in emerging markets. Hence, a fruitful avenue for future research, apart from analyzing the external (international) versus internal (local) spillovers of monetary policy, is whether local macroprudential policies can reduce, or even neutralize, the foreign spillovers into emerging markets stemming from foreign monetary policy in core economic areas, or whether global coordination of monetary policies is the only solution.

\section{APPENDIX}

\section{Table AI}

Variable Definitions (Loan-Month Level)

loan volume

loan maturity

loan collateral

loan rate

loan default

intrate-us

intrate-uk

intrate-euro

intrate-mex

intrate-usr

intrate-ukr

intrate-euror

intrate-fgnr

intrate-mexr

Value of the outstanding loans that a firm has from a given bank in a given month (thousands of Mexican pesos).

Average maturity (in months) of the outstanding loans that a firm has from a given bank in a given month, weighted by loan volume.

Average fraction of the outstanding loans that a firm has from a given bank in a given month that is covered by the firms' assets, weighted by loan volume.

Average annualized loan rate of the outstanding loans that a firm has from a given bank in a given month, weighted by loan volume.

Average fraction of the outstanding loans that a firm has from a given bank in a given month that have been delinquent for at least 90 days, weighted by loan volume.

Fed Funds rate.

SONIA rate.

EONIA rate.

Mexican overnight interest rate (Tasa de Fondeo Interbancaria).

Residual from regression of the Fed Funds rate on the annual growth rate of real GDPU.S. and CPI-U.S..

Residual from regression of the SONIA rate on the annual growth rate of real GDP-U.K. and CPI-U.K..

Residual from regression of the EONIA rate on the annual growth rate of real GDPEurozone and CPI- Eurozone.

Average policy rate residuals of U.K., U.S. and Eurozone weighted by the firm's loan volume from each geographical region.

Residual from regression of Mexican overnight interest rate on the Fed Funds rate and the annual growth rate of real GDP-mex, real GDP-U.S., CPI-mex, and CPI-U.S.. 
Ratio of the annual real change in the Federal Reserve's balance sheet assets to U.S. GDP. each geographical region.

bank-country Indicator variable that equals one if the bank is headquartered in country, where country is U.S., U.K., Eurozone, or Mexico.

gdp-country Seasonally adjusted real GDP annual growth of country, where country is U.S., U.K., Eurozone, or Mexico.

cpi-country

CPI annual growth of country, where country is U.S., U.K., Eurozone, or Mexico.

cds-country

Sovereign credit default swaps (CDS) of country, where country is U.S., U.K., or Eurozone.

Notes: All intrate-country and qe-country variables are lagged one-quarter. 
Table AII

Variable Definitions (Firm-Year Level)

\begin{tabular}{|c|c|}
\hline loan volume ${ }^{Y}$ & $\begin{array}{l}\text { Value of the outstanding loans that a firm has from a given bank in a given year } \\
\text { (thousands of Mexican pesos). }\end{array}$ \\
\hline loan maturity ${ }^{\mathrm{Y}}$ & $\begin{array}{l}\text { Average maturity (in months) of the outstanding loans that a firm has from a } \\
\text { given bank in a given year, weighted by loan volume. }\end{array}$ \\
\hline loan collateral ${ }^{\mathrm{Y}}$ & $\begin{array}{l}\text { Average fraction of the outstanding loans that a firm has from a given bank in a } \\
\text { given year that is covered by the firms' assets, weighted by loan volume. }\end{array}$ \\
\hline loan $\operatorname{rate}^{\mathrm{Y}}$ & $\begin{array}{l}\text { Average annualized loan rate of the outstanding loans that a firm has from a } \\
\text { given bank in a given year, weighted by loan volume. }\end{array}$ \\
\hline loan default ${ }^{\mathrm{Y}}$ & $\begin{array}{l}\text { Average fraction of the outstanding loans that a firm has from a given bank in a } \\
\text { given year that are more than } 90 \text { days in arrears, weighted by loan volume. }\end{array}$ \\
\hline exit $^{\mathrm{Y}}$ & $\begin{array}{l}\text { Proxy for firm survival due to loan defaults. Indicator variable that equals one if a } \\
\text { firm in default exits permanently from the loan-level data set in a given year. }\end{array}$ \\
\hline intrate $^{\mathrm{Y}}$-fgnr $*$ share $^{\mathrm{Y}}$-fgn & $\begin{array}{l}\text { Average annual residuals of monetary policies, weighted by the firm's loan } \\
\text { volume from each geographical region, times the one-year-lagged share of a } \\
\text { firm's loans with foreign banks. }\end{array}$ \\
\hline intrate $^{\mathrm{Y}}$-mexr $*$ share & $\begin{array}{l}\text { Residual of regression of annual overnight Mexican interest rate on Fed Funds } \\
\text { rate, GDP-mex, GDP-us, CPI-mex, CPI-us times the one-year-lagged share of a } \\
\text { firm's loans from Mexican banks. }\end{array}$ \\
\hline $\mathrm{qe}^{\mathrm{Y}}$-fgn $*$ share $^{\mathrm{Y}}$-fgn & $\begin{array}{l}\text { Average annual QE, weighted by the firm's loan volume from each geographical } \\
\text { region, times the one-year-lagged share of a firm's loans from foreign banks. }\end{array}$ \\
\hline $\begin{array}{l}\text { Variables from } \\
\text { assets } \mathrm{Y}\end{array}$ & \\
\hline fixed assets ${ }^{\mathrm{Y}}$ & Total fixed-assets of a firm (thousands of Mexican pesos) in a given year. \\
\hline liabilities $^{\mathrm{Y}}$ & Total liabilities of a firm (thousands of Mexican pesos) in a given year. \\
\hline noncurrent liabilities ${ }^{\mathrm{Y}}$ & $\begin{array}{l}\text { Liabilities of a firm in a given year with a maturity over } 12 \text { months (thousands of } \\
\text { Mexican pesos). }\end{array}$ \\
\hline current liabilities ${ }^{Y}$ & $\begin{array}{l}\text { Liabilities of a firm in a given year with a maturity under } 12 \text { months (thousands } \\
\text { of Mexican pesos). }\end{array}$ \\
\hline employment $^{\mathrm{Y}}$ & Total number of employees of a firm in a given year. \\
\hline
\end{tabular}


Initial submission: March 21, 2015; Accepted: March 24, 2017

Editors: Bruno Biais, Michael R. Roberts, and Kenneth J. Singleton

\section{REFERENCES}

Acharya, Viral and Phillip Schnabl, 2010, Do global banks spread global imbalances? The case of asset-backed commercial paper during the financial crisis of 2007-09, IMF Economic Review 58, 37-73.

Adrian, Tobias, and Hyun Song Shin, 2011, Financial intermediaries and monetary economics, by B. M. Friedman, and M. Woodford eds.: Handbook of Monetary Economics, (Elsevier, New York NY).

Allen, Franklin, and Douglas Gale, 2000, Bubbles and crises, Economic Journal 110, 236255.

Allen, Franklin, and Douglas Gale, 2004, Asset price bubbles and monetary policy, in Global Governance and Financial Crises, (Routledge, London).

Allen, Franklin, and Kenneth Rogoff, 2011, Asset prices, financial stability and monetary policy, in eds.: Inquiry into the Risks in the Swedish Housing Market, P. Jansson, and M. Persson, (Sveriges Riksbank, Stockholm).

Allen, Franklin, Elena Carletti, and Douglas Gale, 2009, Interbank market liquidity and central bank intervention, Journal of Monetary Economics 56, 639-652.

Allen, Franklin, Elena Carletti, and Douglas Gale, 2014, Money, financial stability and efficiency, Journal of Economic Theory 149, 100-127.

Altonji, Joseph, Todd Elder and Christopher Taber, 2005, Selection on observed and unobserved variables: Assessing the effectiveness of catholic schools, Journal of Political Economy $113,151-184$.

Altunbas, Y., Gambacorta, L., and D. Marques, 2014, Does monetary policy affect bank risk? International Journal of Central Banking 10, 95-135.

Banco de Mexico, 2014, Reporte Sobre el Sistema Financiero. 
Beck, Thorsten, and Asli Demirguc-Kunt, 2006, Small and medium-size enterprises: Access to finance as a growth constraint, Journal of Banking \& Finance 30, 2931-2943.

Bernanke, Ben, 1983, Nonmonetary effects of the financial crisis in propagation of the great depression, American Economic Review 73, 257-76.

Bernanke, Ben and Alan Blinder 1992, The federal funds rate and the channels of monetary transmission, American Economic Review 82, 901-921.

Bernanke, Ben and Mark Gertler 1995, Inside the black box: The credit channel of monetary policy transmission, Journal of Economic Perspectives 9, 27-48.

Bernanke, Ben and Cara Lown 1991, The credit crunch, Brookings Papers on Economic Activity 22, 205-248.

Borio, Claudio, and Haibin Zhu 2008, Capital regulation, risk-taking and monetary policy: A missing link in the transmission mechanism, Working Paper, Bank for International Settlements.

Bruno, Valentina and Hyun Shin 2015a, Cross-border banking and global liquidity, Review of Economic Studies 82, 535-564.

Bruno, Valentina and Hyun Shin 2015b, Capital flows and the risk-taking channel of monetary policy, Journal of Monetary Economics 71, 119-132.

Calvo, Guillermo and Carmen Reinhart 2000, When capital inflows come to a sudden stop: Consequences and policy options, in Kenen, P., Swoboda, A. Reforming the International Monetary and Financial System, (International Monetary Fund, Washington, D.C.).

Carabarin, Mauricio, Adrian de la Garza, Othon Moreno 2016, Global liquidity and corporate financing in Mexico, Working Paper, Banco de Mexico.

Cetorelli, Nicola and Linda Goldberg 2012a, Liquidity management of U.S. global banks: Internal capital markets in the great recession, Journal of International Economics 88, 299-311.

Cetorelli, Nicola and Linda Goldberg 2012b, Banking globalization and monetary transmission, Journal of Finance 67, 1811-43.

Claessens, Stijn and Neeltje van Horen 2012, Foreign banks: Trends, impact and financial stability, Working Paper, International Monetary Fund. 
Cuadra, Gabriel, and Victoria Nuguer, Risky banks and macroprudential policy for emerging economies, Working Paper, Banco de México.

De Haas, Ralph, Neeltje van Horen, 2012, International shock transmission after the Lehman Brothers collapse: Evidence from syndicated lending, American Economic Review: Papers \& Proceedings 102, 231-237.

De Haas, Ralph, Neeltje van Horen 2013, Running for the exit? International bank lending during a financial crisis, Review of Financial Studies 26, 244-285.

Dell'Ariccia, Giovanni, Luc Laeven and Gustavo Suarez 2017, Bank leverage and monetary policy's risk-taking channel: Evidence from the United States, Journal of Finance 72, 613-654.

Diamond, Douglas and Raghuram Rajan 2006, Money in a theory of banking, American Economic Review 96, 30-53.

Diamond, Douglas and Raghuram Rajan 2012, Illiquid banks, financial stability, and interest rate policy, Journal of Political Economy 120, 552-591.

European Central Bank 2009, Recent developments in the balance sheets of the Eurosystem, the Federal Reserve System and the Bank of Japan, ECB Monthly Bulletin October, 81-94.

European Central Bank 2011, The Monetary Policy of the ECB, Third edition, May.

Fischer, Stanley 2014, The Federal Reserve and the Global Economy, Speech by Vice Chairman of the Board of Governors of the Federal Reserve System delivered as the Per Jacobsson Foundation Lecture, Annual Meetings of the International Monetary Fund and the World Bank Group Washington.

Gertler, Mark, and Peter Karadi. 2011, A model of unconventional monetary policy, Journal of Monetary Economics 58, 17-34.

Gertler, Mark, and Peter Karadi. 2015, Monetary policy surprises, credit costs, and economic activity, American Economic Journal: Macroeconomics 7, 44-76.

Gertler, Mark and Nobuhiro Kiyotaki 2010, Financial intermediation and credit policy in business cycle analysis, in B. M. Friedman and M. Woodford, eds: Handbook of Monetary Economics. 
Giannetti, Mariassunta and Luc Laeven. 2012, The flight home effect: Evidence from the syndicated loan market during financial crises, Journal of Financial Economics 104, 23-43.

Gourinchas, Pierre-Olivier \& Maurice Obstfeld, 2012, Stories of the twentieth century for the twenty-first, American Economic Journal: Macroeconomics 4, 226-65.

IMF 2012, Mexico: Financial Stability Assessment, IMF Country Report No. 12/65.

INEGI 2014, Exportaciones por Entidad Federativa.

Ioannidou, Vasso, Steven Ongena, and Jose-Luis Peydró 2015, Monetary policy, risk- taking and pricing: Evidence from a quasi-natural experiment, Review of Finance 19, 95-144.

Jeon, Bang, Olivero, Maria Pia Olivero, Ji Wu 2013, Multinational banking and the international transmission of financial shocks: Evidence from foreign bank subsidiaries, Journal of Banking and Finance 37, 952-972.

Jiménez, Gabriel, Steven Ongena, Jose-Luis. Peydró, and Jesus Saurina 2012, Credit supply and monetary policy: Identifying the bank balance-sheet channel with loan applications, American Economic Review 102, 2301-26.

Jiménez, Gabriel, Steven Ongena, Jose-Luis. Peydró, and Jesus Saurina 2014, Hazardous times for monetary policy: What do twenty-three million bank loans say about the effects of monetary policy on credit risk-taking? Econometrica 822, 463-505.

Jordà, Òscar and Moritz Schularick and Alan Taylor, 2011, Financial Crises, Credit Booms, and External Imbalances: 140 Years of Lessons, IMF Economic Review 592, 340-378.

Kalemli-Ozcan, Sebnem, Elias Papaioannou, and Jose-Luis Peydró 2013, Financial regulation, financial globalization, and the synchronization of economic activity, Journal of Finance $68,1179-1228$.

Kashyap, Anil, and Jeremy Stein 2000, What do a million observations on banks say about the transmission of monetary policy? American Economic Review 90, 407-428.

Khwaja, Asim, and Atif Mian 2008, Tracing the Impact of Bank Liquidity Shocks: Evidence from an emerging market, American Economic Review 98, 1413-42. 
Kiyotaki, Nobuhiro and John Moore 2012, Liquidity, business cycles, and monetary policy, NBER Working Papers 17934, National Bureau of Economic Research.

Lang, Larry, Eli Ofek, and Rene Stulz 1996, Leverage, investment and firm growth, Journal of Financial Economics 40, 3-29.

Maddaloni, Angela, and Jose-Luis Peydró 2011, Bank risk-taking, Securitization, supervision, and low interest rates: Evidence from Euro-Area and U.S. lending standards, Review of Financial Studies 24, 2121-2165.

Mian, Atif 2006, Distance Constraints: The limits of foreign lending in poor economies, Journal of Finance 61, 1465-1505.

Mian, Atif, and Amir Sufi. 2014, What explains the 2007-2009 drop in employment, Econometrica 82, 2197-2223.

Miranda-Agrippino, Silvia, and Helene Rey 2015, World asset markets and the global Financial Cycle Mimeo.

Ongena Steven and David Smith, 2001, The duration of bank relationships, Journal of Financial Economics 61, 449-475.

Paligorova, Teodora, and Joao Santos 2017, Monetary policy and bank risk-taking: Evidence from the corporate loan market, Journal of Financial Intermediation 30, 35-49

Peek, Joe, and Eric Rosengren 2000, Collateral Damage: Effects of the Japanese bank crisis on real activity in the United States, American Economic Review 90, 30-45.

Popov, Alexander, Gregory Udell, 2012, Cross-border banking, credit access, and the financial crisis, Journal of International Economics 87, 147-161.

Rajan, Raghuram 2005, Has finance made the world riskier? Speech presented at Jackson Hole, Federal Reserve Bank, Federal Reserve Bank, August.

Rajan, Raghuram 2014, Competitive monetary easing: Is it yesterday once more? Speech at the Brookings Institution.

Reinhart, Carmen, and Kenneth Rogoff 2009, This Time is Different: Eight Centuries of Financial Folly, (Princeton University Press, Princeton, NJ). 
Rey, Helene 2013, Dilemma not trilemma: The global financial cycle and monetary policy independence, paper presented at Global Dimensions of Unconventional Monetary Policy, Jackson Hole, Federal Reserve Bank, August 22-24.

Schnabl, Philipp 2012, The international transmission of bank liquidity shocks: Evidence from an emerging market, Journal of Finance 67, 897-932.

Schularick, Moritz, and Alan Taylor 2012, Credit booms gone bust: Monetary policy, leverage cycles, and financial crises, 1870-2008, American Economic Review 102, 1029-61.

Shleifer, Andrei, and Robert Vishny, 2010, Unstable banking, Journal of Financial Economics 97, 306-318.

Stein, Jeremy 1998, An adverse-selection model of bank asset and liability management with implications for the transmission of monetary policy. RAND Journal of Economics 29 , 466-486.

Stein, Jeremy 2013, Overheating in credit markets: Origins, measurement, and policy responses, speech by Federal Reserve Board Governor Jeremy Stein, February 7, 2013.

Stiglitz, Joseph and Andrew Weiss, 1981, Credit rationing in markets with imperfect information. American Economic Review 71, 393-410. 
Table I

\section{Summary Statistics}

This table reports the definitions for all variables. Loan-level data at the loan-month and firm-year levels comprise 8,268,794 and 747,910 observations, respectively, and 14,563 firm-year observations from Orbis (see Tables AI and AII in the Appendix for more detailed information); all variables from the Orbis sample are in thousands of Mexican pesos, except employment ${ }^{Y}$.

\begin{tabular}{|c|c|c|c|}
\hline Variable & Mean & Median & St. Dev \\
\hline \multicolumn{4}{|l|}{ Variables at the Loan-Month Level } \\
\hline loan volume (thousands of Mexican pesos) & 2,244 & 379 & 6,168 \\
\hline loan maturity (months) & 33.2 & 36.0 & 21.1 \\
\hline loan collateral & 0.26 & 0.00 & 0.52 \\
\hline loan rate & 0.15 & 0.15 & 0.07 \\
\hline loan default & 0.07 & 0.00 & 0.26 \\
\hline intrate-us & 0.015 & 0.002 & 0.019 \\
\hline intrate-uk & 0.024 & 0.005 & 0.022 \\
\hline intrate-euro & 0.017 & 0.010 & 0.015 \\
\hline intrate-mex & 0.058 & 0.046 & 0.018 \\
\hline intrate-usr & -0.002 & -0.007 & 0.017 \\
\hline intrate-ukr & 0.000 & -0.002 & 0.020 \\
\hline intrate-euror & 0.000 & -0.003 & 0.012 \\
\hline intrate-fgnr & 0.000 & 0.000 & 0.014 \\
\hline intrate-mexr & 0.000 & -0.001 & 0.010 \\
\hline qe-us & 0.022 & 0.013 & 0.027 \\
\hline qe-uk & 0.018 & 0.004 & 0.030 \\
\hline qe-euro & 0.015 & 0.013 & 0.032 \\
\hline qe-fgn & 0.002 & 0.000 & 0.028 \\
\hline bank-us & 0.152 & 0.000 & 0.359 \\
\hline bank-uk & 0.134 & 0.000 & 0.341 \\
\hline bank-euro & 0.323 & 0.000 & 0.468 \\
\hline bank-mex & 0.386 & 0.000 & 0.487 \\
\hline \multicolumn{4}{|l|}{ Variables at the Firm-Year Level } \\
\hline loan volume ${ }^{\mathrm{Y}}$ (thousands of Mexican pesos) & 25,795 & 3,304 & 86,906 \\
\hline loan maturity ${ }^{\mathrm{Y}}$ (months) & 33.1 & 34.3 & 22.8 \\
\hline loan collateral ${ }^{\mathrm{Y}}$ & 0.27 & 0.00 & 0.57 \\
\hline loan rate $^{\mathrm{Y}}$ & 0.15 & 0.15 & 0.08 \\
\hline loan default ${ }^{\mathrm{Y}}$ & 0.06 & 0.00 & 0.24 \\
\hline $\operatorname{exit}^{Y}$ & 0.04 & 0.00 & 0.19 \\
\hline intrate $^{\mathrm{Y}}$-fgnr* share $^{\mathrm{Y}}$-fgn & 0.000 & 0.000 & 0.010 \\
\hline intrate $^{\mathrm{Y}}$-mexr* share $^{\mathrm{Y}}$-mex & 0.000 & 0.000 & 0.004 \\
\hline $\mathrm{qe}^{\mathrm{Y}}$-fgn* share $^{\mathrm{Y}}$-fgn & 0.001 & 0.000 & 0.022 \\
\hline \multicolumn{4}{|l|}{ Variables at the Firm-Year Level (Orbis sample) } \\
\hline fixed assets ${ }^{\mathrm{Y}}$ & 95,202 & 3,042 & 354,762 \\
\hline liabilities ${ }^{\mathrm{Y}}$ & 110,190 & 9,350 & 362,078 \\
\hline noncurrent liabilities ${ }^{\mathrm{Y}}$ & 22,949 & 0 & 94,264 \\
\hline current liabilities $^{\mathrm{Y}}$ & 82,555 & 8,180 & 216,639 \\
\hline employment ${ }^{\mathrm{Y}}$ (units) & 115 & 40 & 177 \\
\hline
\end{tabular}


Table II, Panel A

Impact of International Monetary Policies on Domestic Loan Volume

This table reports the estimates from OLS regressions for the period June 2001 to December 2015. Observations are at the firm-bank-month level. The dependent variable is the volume of loans, in logs, from a firm with a bank in a given month. intrate-countryr is the residual policy rate of country, where country stands for U.S., U.K., Euro Area, or Mexico. qe-country is the ratio of the annual real change in central bank assets to GDP of country. bank- country is a dummy indicating whether bank headquarters are in country. Other controls are listed in Section II. Fixed effects already absorbed by other fixed effects are indicated by "_.". Standard errors are reported in parentheses and are clustered at the period and bank-industry levels, where period is month. ***,*** significant at the $10 \%, 5 \%$ and $1 \%$ level respectively.

\section{(1)}

$-0.19$

intrate-usr

intrate-usr * bank-us

intrate-ukr

intrate-ukr * bank-uk

intrate-euror

intrate-euror * bank-euro

intrate-mexr

intrate-mexr * bank-mex

qe-us

qe-us * bank-us

qe-uk

qe-uk * bank-uk

qe-euro

qe-euro * bank-euro

Firm*Bank F.E.

State*Industry*Period F.E.

Firm*Period F.E.

Firms borrowing from more than 1 bank

Observations

$\mathrm{R}^{2}$
$-2.93 * * *$

$(0.34)$

$-0.11$

$(0.30)$

$-1.05^{* *}$

$(0.49)$

$2.05 * * *$

$-3.55^{* * *}$

(0.40)

$-2.42 * * *$

$(0.54)$

$(0.63)$

$-2.10^{* *}$

(0.82)

$-0.59 * * *$

(0.19)

$-0.03$

(0.32)

$-0.52 * * *$

(0.10)

$0.56 * *$

(0.26)

$-0.04$

(0.11)

$0.65^{* * *}$

(0.19)

$0.13^{*}$

(0.07)

$0.37 * * *$

(0.12)

$-1.70^{*}$

(0.97)

$-1.12 * *$

(0.54)

$-2.11 * * *$

(0.46)

$-3.21 * *$
$(0.35)$

$-3.31 * * *$

(0.54)

$-2.45^{* * *}$

(0.74)

$-0.63$

(0.82)

0.58

(0.47)

$-0.03$

(0.47)

$-0.10$

(0.75)

$0.95^{* * *}$

$0.85^{* * *}$

$(0.20)$

$0.90 * * *$

(0.26)

$0.70 * *$

$0.58 *$

(0.32)

0.55

(0.48)

0.07

(0.14)

0.10

0.06

(0.10)

(0.16)

Yes

No

No

No

Yes

Yes

No

No
Yes

Yes

No

Yes
Yes

-

Yes

Yes

\begin{tabular}{cccc}
$8,268,794$ & $8,268,794$ & $3,020,617$ & $3,020,617$ \\
0.01 & 0.03 & 0.04 & 0.47 \\
\hline
\end{tabular}


Table II, Panel B

\section{Impact of International Monetary Policies on Other Domestic Credit Margins}

This table reports the estimates from OLS regressions for the period June 2001 to December 2015. Observations are at the firm-bank-month level. The loan dependent variables (given by a bank in a month) are the firms' log loan maturity in months, collateral rate, loan rate and default in $t+12$ in a given month. intrate-countryr is the residual of policy rate of country, where country stands for U.S., U.K., Euro Area, or Mexico. qe-country is the ratio of the annual real change in central bank assets to GDP of country. bank- country is a dummy indicating whether bank headquarters are in country. Other controls are listed in Section II. Fixed effects already absorbed by other fixed effects are indicated by "-“.

Standard errors are reported in parentheses and are clustered at the period and bank-industry levels, where period is month. *,**,*** significant at the $10 \%, 5 \%$ and $1 \%$ level respectively.

\begin{tabular}{|c|c|c|c|c|c|c|c|c|}
\hline & Loan & turity & Loan & ateral & Loc & ate & Loan & fault \\
\hline & $(1)$ & $(2)$ & (3) & (4) & $(5)$ & (6) & (7) & $(8)$ \\
\hline intrate-usr * bank-us & $-5.80 * * *$ & $-5.79 * * *$ & $-0.66 * * *$ & $-0.86^{* * *}$ & $0.16^{* *}$ & $0.16^{* * *}$ & $-0.48^{*}$ & $-0.59 * *$ \\
\hline & $(1.60)$ & $(1.63)$ & $(0.18)$ & $(0.22)$ & $(0.09)$ & $(0.05)$ & $(0.28)$ & $(0.28)$ \\
\hline intrate-ukr * bank-uk & $-9.17 * * *$ & $-8.63 * * *$ & $-0.98 * * *$ & $-0.85 * * *$ & -0.01 & 0.01 & $-0.62 * *$ & -0.09 \\
\hline & $(0.89)$ & $(1.35)$ & $(0.16)$ & $(0.20)$ & $(0.01)$ & $(0.11)$ & $(0.25)$ & $(0.34)$ \\
\hline intrate-euror * bank-euro & 1.13 & 0.70 & $-1.95 * * *$ & $-2.16 * * *$ & 0.05 & 0.04 & $-0.61 *$ & $-0.59 *$ \\
\hline & $(1.20)$ & $(1.37)$ & $(0.28)$ & $(0.36)$ & $(0.07)$ & $(0.10)$ & $(0.35)$ & $(0.35)$ \\
\hline intrate-mexr * bank-mex & $2.35 * * *$ & $1.48^{*}$ & $-0.35^{*}$ & -0.40 & -0.06 & -0.02 & 0.25 & 0.44 \\
\hline & $(0.75)$ & $(0.85)$ & $(0.19)$ & $(0.26)$ & $(0.04)$ & $(0.07)$ & $(0.18)$ & $(0.30)$ \\
\hline qe-us * bank-us & $2.64 * * *$ & $2.90 * * *$ & 0.08 & 0.07 & $-0.09 * * *$ & $-0.10^{* *}$ & $0.13^{*}$ & $0.14^{*}$ \\
\hline & $(0.82)$ & $(0.87)$ & $(0.12)$ & $(0.14)$ & $(0.03)$ & $(0.04)$ & $(0.07)$ & $(0.08)$ \\
\hline qe-uk * bank-uk & 0.65 & 0.28 & -0.08 & -0.03 & -0.01 & 0.01 & $0.18^{*}$ & 0.19 \\
\hline & $(0.54)$ & $(0.72)$ & $(0.10)$ & $(0.14)$ & $(0.01)$ & $(0.09)$ & $(0.10)$ & $(0.20)$ \\
\hline qe-euro $*$ bank-euro & -0.08 & 0.01 & $0.16^{* *}$ & 0.12 & $0.03 * * *$ & $0.03 * *$ & 0.05 & 0.09 \\
\hline & $(0.26)$ & $(0.28)$ & $(0.07)$ & $(0.09)$ & $(0.01)$ & $(0.01)$ & $(0.07)$ & $(0.11)$ \\
\hline Firm*Bank F.E. & Yes & Yes & Yes & Yes & Yes & Yes & Yes & Yes \\
\hline State*Industry*Period F.E. & Yes & - & Yes & - & Yes & - & Yes & - \\
\hline Firm*Period F.E. & No & Yes & No & Yes & No & Yes & No & Yes \\
\hline Firms borrowing from more than 1 bank & No & Yes & No & Yes & No & Yes & No & Yes \\
\hline Observations & $8,268,794$ & $3,020,617$ & $8,268,794$ & $3,020,617$ & $8,268,794$ & $3,020,617$ & $6,537,533$ & $2,301,790$ \\
\hline $\mathrm{R}^{2}$ & 0.17 & 0.54 & 0.04 & 0.46 & 0.23 & 0.58 & 0.03 & 0.57 \\
\hline
\end{tabular}


Table II, Panel C

\section{Impact of 3-month to 12-month lagged International Monetary Policies on Domestic Credit Margins}

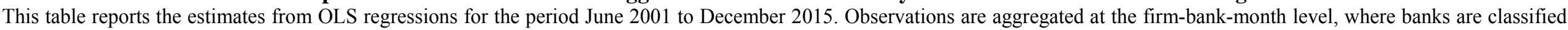

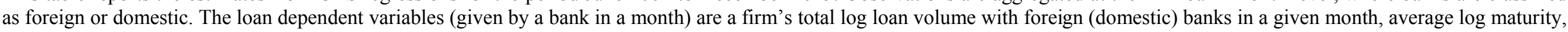

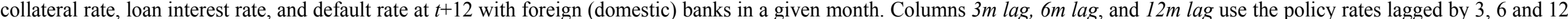

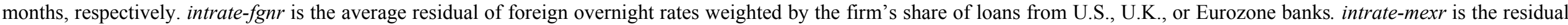

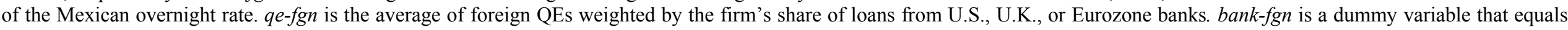

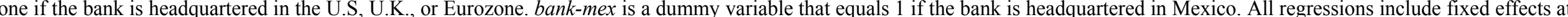

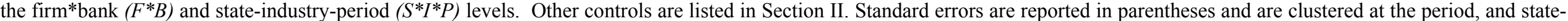
industry levels, where period is a month. $*, * *, * * *$ significant at the $10 \%, 5 \%$ and $1 \%$ level respectively.

\begin{tabular}{|c|c|c|c|c|c|c|c|c|c|c|c|c|c|c|c|}
\hline & \multicolumn{3}{|c|}{ Loan Volume } & \multicolumn{3}{|c|}{ L Loan Maturity } & \multicolumn{3}{|c|}{ Loan Collateral } & \multicolumn{3}{|c|}{ Loan Rate } & \multicolumn{3}{|c|}{ Loan Default } \\
\hline & $3 \mathrm{~m} \mathrm{lag}$ & $6 \mathrm{~m} \mathrm{lag}$ & $12 \mathrm{~m} \mathrm{lag}$ & $3 \mathrm{~m} \mathrm{lag}$ & $6 \mathrm{~m} \mathrm{lag}$ & $12 \mathrm{~m} \mathrm{lag}$ & $3 \mathrm{~m} \mathrm{lag}$ & $6 \mathrm{~m} \mathrm{lag}$ & $12 \mathrm{~m} \mathrm{lag}$ & $3 \mathrm{~m} \mathrm{lag}$ & $6 \mathrm{~m} \mathrm{lag}$ & $12 \mathrm{~m} \mathrm{lag}$ & $3 \mathrm{~m} \mathrm{lag}$ & $6 \mathrm{~m} \mathrm{lag}$ & $12 \mathrm{~m} \mathrm{lag}$ \\
\hline & (1) & (2) & (3) & (4) & (5) & (6) & (7) & (8) & (9) & (10) & (11) & (12) & (13) & (14) & (15) \\
\hline intrate-fgnr & $-1.46^{* *}$ & $-1.81 * * *$ & $-2.05 * * *$ & $-4.81 * * *$ & $-4.72 * * *$ & $-4.29 * * *$ & $-1.09 * * *$ & $-1.25 * * *$ & $-1.34 * * *$ & 0.04 & $0.07 *$ & $0.20 * * *$ & $-0.49 * * *$ & $-0.49 * * *$ & $-0.26^{*}$ \\
\hline *bank-fgn & $(0.58)$ & $(0.57)$ & $(0.46)$ & $(1.16)$ & $(1.21)$ & (1.13) & $(0.33)$ & $(0.32)$ & $(0.28)$ & $(0.04)$ & $(0.04)$ & $(0.02)$ & $(0.14)$ & $(0.13)$ & $(0.13)$ \\
\hline intrate-mexr & 0.06 & 0.50 & 0.25 & $2.50 * * *$ & $2.94 * * *$ & $3.41 * * *$ & $-0.79 * * *$ & -0.34 & $0.71 * * *$ & 0.04 & $0.10^{* *}$ & $0.06^{* *}$ & 0.28 & 0.2 & 0.18 \\
\hline *bank-mex & $(0.34)$ & $(0.40)$ & $(0.28)$ & $(0.84)$ & $(0.82)$ & $(0.89)$ & $(0.26)$ & $(0.25)$ & $(0.20)$ & $(0.04)$ & $(0.04)$ & $(0.02)$ & $(0.21)$ & $(0.17)$ & $(0.17)$ \\
\hline qe-fgn & $0.31^{* *}$ & $0.46 * * *$ & $0.50 * * *$ & $1.00 * * *$ & $1.35^{* * *}$ & $1.34 * * *$ & $0.17 * * *$ & $0.13 * *$ & 0.08 & 0.01 & 0.01 & 0.01 & 0.03 & 0.05 & $0.21 * * *$ \\
\hline *bank-fgn & $(0.11)$ & $(0.09)$ & $(0.09)$ & $(0.24)$ & $(0.23)$ & $(0.25)$ & $(0.06)$ & $(0.05)$ & $(0.06)$ & $(0.01)$ & $(0.01)$ & $(0.01)$ & $(0.05)$ & $(0.05)$ & $(0.04)$ \\
\hline $\mathrm{F}^{*}$ B F.E. & Yes & Yes & Yes & Yes & Yes & Yes & Yes & Yes & Yes & Yes & Yes & Yes & Yes & Yes & Yes \\
\hline S*I*P F.E. & Yes & Yes & Yes & Yes & Yes & Yes & Yes & Yes & Yes & Yes & Yes & Yes & Yes & Yes & Yes \\
\hline Obs. & $7,046,918$ & $7,046,918$ & $7,046,918$ & $7,046,918$ & $7,046,918$ & $7,046,918$ & $7,046,918$ & $7,046,918$ & $7,046,918$ & $7,046,918$ & $7,046,918$ & $7,046,918$ & $5,196,351$ & $5,196,351$ & $5,196,351$ \\
\hline $\mathrm{R}^{2}$ & 0.03 & 0.03 & 0.03 & 0.13 & 0.13 & 0.13 & 0.04 & 0.04 & 0.04 & 0.18 & 0.18 & 0.19 & 0.03 & 0.03 & 0.03 \\
\hline
\end{tabular}




\section{Table III}

\section{Impact of International Monetary Policy on Domestic Firm-Level Real Effects and Credit Outcomes}

This table reports the estimates from OLS regressions for the period 2001 to 2015. Observations are aggregated at the firm-year level. The first six columns use information from the loan-level data set and refer to a firm's loan volume in logs, maturity in logs, collateral rate, loan interest rate, and one-year-ahead default rate as well as a proxy for firm survival. The last six columns restrict the sample to firms that are observed in both the loan-level data set and in the Orbis data set. The dependent variables are a firm's log liabilities (total, current, non-current), log assets (total and fixed), and employment in a given year. intrate -fgnr is the annual average of the residual of foreign overnight rates

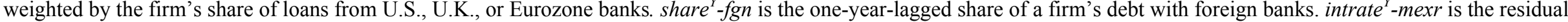
of the Mexican overnight rate. share $e^{Y}$ - mex is a firm's one-year-lagged-share of loans from Mexican banks. $q e^{Y}-f g n$ is the average of foreign QE weighted by the firm's share of loans from U.S., U.K., or Eurozone banks. share -fgn is the one-year-lagged share of a firm's bank debt from foreign banks. All regressions include fixed effects at the firm and state*industry*year level. Standard errors are reported in parentheses and are clustered at the state*year level. *,**,*** significant at the $10 \%, 5 \%$ and $1 \%$ level respectively.

\begin{tabular}{|c|c|c|c|c|c|c|c|c|c|c|c|c|}
\hline & $\begin{array}{c}\text { Credit } \\
\text { Volume }\end{array}$ & $\begin{array}{c}\text { Credit } \\
\text { Maturity }\end{array}$ & $\begin{array}{c}\text { Credit } \\
\text { Collateral }\end{array}$ & $\begin{array}{l}\text { Credit } \\
\text { Rate }\end{array}$ & $\begin{array}{c}\text { Credit } \\
\text { Default }\end{array}$ & Exit & Liabilities & $\begin{array}{c}\text { Current } \\
\text { Liabilities }\end{array}$ & $\begin{array}{c}\text { Non- } \\
\text { Current } \\
\text { Liabilities }\end{array}$ & Assets & $\begin{array}{l}\text { Fixed } \\
\text { Assets }\end{array}$ & Employment \\
\hline & $(1)$ & $(2)$ & (3) & $(4)$ & $(5)$ & $(6)$ & (7) & $(8)$ & $(9)$ & $(10)$ & $(11)$ & $(12)$ \\
\hline \multirow[t]{2}{*}{ intrate $^{Y}$-fgnr* share ${ }^{Y}$-fgn } & $-1.54^{*}$ & $-4.92 * *$ & $-1.32 * *$ & $0.12^{*}$ & $-0.32 *$ & $0.92 *$ & $-1.20^{* *}$ & $-1.26^{* * *}$ & $-2.08^{* *}$ & $-0.76^{*}$ & $-0.45^{*}$ & $-0.34 *$ \\
\hline & $(0.89)$ & $(1.88)$ & $(0.52)$ & $(0.07)$ & $(0.19)$ & $(0.54)$ & $(0.40)$ & $(0.38)$ & $(0.65)$ & $(0.39)$ & $(0.25)$ & $(0.20)$ \\
\hline \multirow[t]{2}{*}{ intrate $^{\mathrm{Y}}$-mexr* share $^{\mathrm{Y}}$-mex } & $3.28 *$ & 4.37 & 0.16 & -0.02 & 0.05 & -0.22 & 0.43 & 0.93 & -1.23 & $0.85 * *$ & $1.19 * * *$ & 0.27 \\
\hline & $(1.83)$ & $(3.85)$ & $(2.23)$ & $(0.10)$ & $(0.68)$ & $(0.70)$ & $(0.69)$ & $(0.61)$ & $(2.88)$ & $(0.31)$ & $(0.15)$ & $(0.57)$ \\
\hline \multirow{2}{*}{$\mathrm{qe}^{\mathrm{Y}}$-fgn* share ${ }^{\mathrm{Y}}$-fgn } & 0.24 & 0.95 & $0.39 * *$ & 0.03 & $0.14^{*}$ & 0.02 & 0.20 & 0.09 & 0.43 & 0.15 & $0.68 * * *$ & -0.06 \\
\hline & $(0.31)$ & $(0.96)$ & $(0.18)$ & $(0.04)$ & $(0.08)$ & $(0.10)$ & $(0.16)$ & $(0.20)$ & $(0.40)$ & $(0.15)$ & $(0.12)$ & $(0.12)$ \\
\hline Firm F.E. & Yes & Yes & Yes & Yes & Yes & Yes & Yes & Yes & Yes & Yes & Yes & Yes \\
\hline State*Industry*Year F.E. & Yes & Yes & Yes & Yes & Yes & Yes & Yes & Yes & Yes & Yes & Yes & Yes \\
\hline Observations & 747,910 & 747,910 & 747,910 & 747,910 & 735,240 & 747,913 & 13,918 & 13,918 & 13,918 & 14,563 & 14,563 & 13,838 \\
\hline $\mathrm{R}^{2}$ & 0.09 & 0.14 & 0.04 & 0.17 & 0.03 & 0.04 & 0.20 & 0.20 & 0.25 & 0.26 & 0.22 & 0.19 \\
\hline
\end{tabular}


Table IV

Impact of International Monetary Policies on Domestic Credit Margins by Ex-Ante Loan Rates

This table reports the estimates from OLS for the period June 2001 to December 2015. Observations are at the firm-bank-month level. A firm-bank-period observation is high (low) yield if the interest rate it pays on its loans is above (below) the average loan interest rate, weighted by loan volume, paid by all firms in the previous quarter for all loans. The dependent variables are a firm's log loan volume, log maturity in months, collateral rate, loan rate and future default rate (at period $t+12$ ) with a given bank in a given month. intratecountryr is the residual policy rate of country, where country stands for U.S., U.K., Euro Area, or Mexico. qe-country is the ratio of the annual real change in central bank assets to GDP of country. bank-country is a dummy indicating whether the bank's headquarters are in country. Other controls are listed in Section II. Standard errors clustered at the period and bank-industry levels are reported in parentheses, where period is month. ${ }^{*}, * * * *$ significant at the $10 \%, 5 \%$ and $1 \%$ level respectively.

\begin{tabular}{|c|c|c|c|c|c|c|c|c|c|c|}
\hline & \multicolumn{2}{|c|}{ Loan Volume } & \multicolumn{2}{|c|}{ Loan Maturity } & \multicolumn{2}{|c|}{ Loan Collateral } & \multicolumn{2}{|c|}{ Loan Rate } & \multicolumn{2}{|c|}{ Loan Default } \\
\hline & High yield & Low yield & High yield & Low yield & High yield & Low yield & High yield & Low yield & High yield & Low yield \\
\hline & (1) & $(2)$ & (3) & (4) & $(5)$ & (6) & (7) & $(8)$ & (9) & $(10)$ \\
\hline \multirow[t]{2}{*}{ intrate-usr* bank-us } & $-3.92 * * *$ & $-2.28 * * *$ & $-6.46 * * *$ & $-0.89 * *$ & $-0.59 * * *$ & $-1.40 * * *$ & $0.20 * * *$ & 0.02 & $-0.59 *$ & $0.58 * *$ \\
\hline & $(0.43)$ & $(0.69)$ & $(1.78)$ & $(0.45)$ & $(0.15)$ & $(0.42)$ & $(0.03)$ & $(0.04)$ & $(0.35)$ & $(0.26)$ \\
\hline \multirow[t]{2}{*}{ intrate-ukr* bank-uk } & $-2.75 * * *$ & -0.34 & $-9.47 * * *$ & 0.22 & $-1.08 * * *$ & $-0.82 *$ & 0.02 & 0.01 & $-0.55^{*}$ & 0.19 \\
\hline & $(0.59)$ & $(0.87)$ & $(1.00)$ & $(0.52)$ & $(0.15)$ & $(0.48)$ & $(0.08)$ & $(0.10)$ & $(0.29)$ & $(0.33)$ \\
\hline \multirow[t]{2}{*}{ intrate-euror* bank- euro } & $-2.51 * *$ & -1.04 & 1.36 & $2.35 * * *$ & $-2.31 * * *$ & -0.71 & $0.15^{*}$ & 0.04 & -0.35 & -0.24 \\
\hline & $(1.13)$ & $(1.14)$ & $(1.33)$ & $(0.61)$ & $(0.30)$ & $(0.54)$ & $(0.09)$ & $(0.06)$ & $(0.53)$ & $(0.52)$ \\
\hline \multirow[t]{2}{*}{ intrate-mexr* bank-mex } & $0.80 *$ & 1.23 & $2.72 * * *$ & -0.21 & -0.32 & 0.01 & $-0.10 *$ & -0.06 & 0.20 & 0.21 \\
\hline & $(0.45)$ & $(0.75)$ & $(0.76)$ & $(0.69)$ & $(0.21)$ & $(0.42)$ & $(0.06)$ & $(0.06)$ & $(0.20)$ & $(0.18)$ \\
\hline \multirow[t]{2}{*}{ qe-us* bank-us } & $0.94 * * *$ & 0.49 & $3.08 * * *$ & 0.44 & 0.15 & $-0.70 *$ & $-0.10 * *$ & 0.02 & $0.20 * * *$ & -0.02 \\
\hline & $(0.28)$ & $(0.31)$ & $(0.84)$ & $(0.28)$ & $(0.09)$ & $(0.37)$ & $(0.04)$ & $(0.02)$ & $(0.07)$ & $(0.11)$ \\
\hline \multirow[t]{2}{*}{ qe-uk* bank-uk } & $0.70^{*}$ & 0.03 & 0.74 & -0.73 & -0.07 & 0.22 & -0.01 & -0.02 & $0.20 *$ & 0.22 \\
\hline & $(0.38)$ & $(0.40)$ & $(0.58)$ & $(0.48)$ & $(0.08)$ & $(0.44)$ & $(0.05)$ & $(0.07)$ & $(0.10)$ & $(0.24)$ \\
\hline \multirow[t]{2}{*}{ qe-euro* bank-euro } & 0.01 & -0.24 & -0.13 & $0.45 * * *$ & $0.10^{*}$ & 0.26 & $0.04 * * *$ & 0.01 & $0.13^{* *}$ & 0.06 \\
\hline & $(0.12)$ & $(0.17)$ & $(0.27)$ & $(0.13)$ & $(0.06)$ & $(0.17)$ & $(0.01)$ & $(0.01)$ & $(0.07)$ & $(0.07)$ \\
\hline Firm*Bank F.E. & Yes & Yes & Yes & Yes & Yes & Yes & Yes & Yes & Yes & Yes \\
\hline State*Industry*Period F.E. & Yes & Yes & Yes & Yes & Yes & Yes & Yes & Yes & Yes & Yes \\
\hline Observations & $7,110,956$ & $1,157,838$ & $7,110,956$ & $1,157,838$ & $7,110,956$ & $1,157,838$ & $7,110,956$ & $1,157,838$ & $5,602,833$ & 934,700 \\
\hline $\mathrm{R}^{2}$ & 0.03 & 0.09 & 0.21 & 0.08 & 0.04 & 0.10 & 0.25 & 0.29 & 0.03 & 0.10 \\
\hline
\end{tabular}




\section{Figure 1}

Monetary policies and quantitative easing June 2001- December 2015.

The first figure plots the residuals from regressions of the foreign monetary policies (EONIA rate for the Eurozone, SONIA rate for the U.K. and Fed Funds rate for the U.S.) on the annual growth rate of real GDP and $\mathrm{CPI}$ of each region over time, as well as the residuals from a regression of the Mexican monetary policy (Tasa de Fondeo Bancario) on the Fed Funds, and the annual growth rates of CPI and real GDP for both Mexico and the U.S. The second figure plots the evolution of quantitative easing over time in the Eurozone, U.K., and U.S., respectively. Quantitative easing is measured as the annual real change in total balance sheet assets of each central bank (ECB, BoE, and Federal Reserve) as a share of GDP in each region.
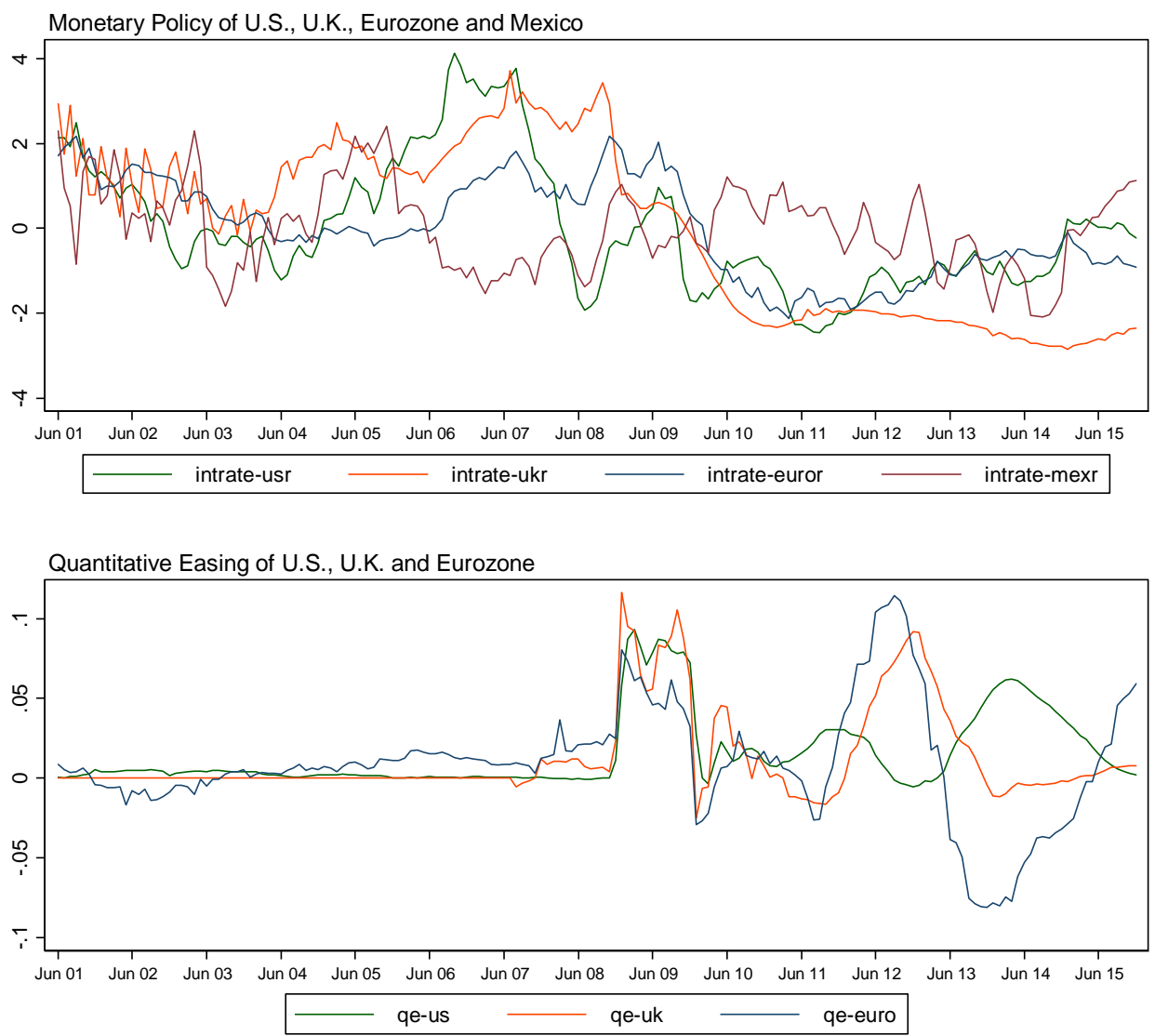
Table IAI

Summary Statistics, Monthly Bank-Level Data

This table reports balance sheet information of banks. Assets are measured in logs of billions of real Mexican Pesos in January 2008 prices. Liquidity ratio is the ratio of liquid assets to total assets. Capital ratio is the ratio of equity to total assets. Deposit ratio is the ratio of total deposits to assets. ROA is return on assets, measured as the ratio of net income to assets. $R O E$ is return on equity, measured as the ratio of net income to equity. Commercial credit is the ratio of commercial credit to total assets. Market share is the bank's market share of commercial credit. Standard deviations are reported in parentheses. Statistics cover the period June 2001 to December 2015. The panel under Commercial Loan Portfolio Composition gives the share of commercial credit allocated by a bank to firms in the Agriculture, Construction, Manufacturing, Retail, Services, and Other Sectors.

\begin{tabular}{|c|c|c|c|c|c|}
\hline & $\begin{array}{c}\text { All banks } \\
\text { (1) }\end{array}$ & $\begin{array}{l}\text { Mex banks } \\
\text { (large) } \\
\text { (2) }\end{array}$ & $\begin{array}{c}\text { Euro Area } \\
\text { Banks } \\
\text { (3) }\end{array}$ & $\begin{array}{c}\text { U.K. Banks } \\
\text { (4) }\end{array}$ & $\begin{array}{c}\text { U.S. Banks } \\
\text { (5) }\end{array}$ \\
\hline \multicolumn{6}{|c|}{ Balance Sheet Information } \\
\hline Assets (logs) & $\begin{array}{c}4.4 \\
(1.8)\end{array}$ & $\begin{array}{c}6.0 \\
(0.6)\end{array}$ & $\begin{array}{c}6.4 \\
(0.1)\end{array}$ & $\begin{array}{c}5.8 \\
(0.5)\end{array}$ & $\begin{array}{c}6.6 \\
(0.5)\end{array}$ \\
\hline Liquidity ratio & $\begin{array}{c}0.09 \\
(0.05)\end{array}$ & $\begin{array}{c}0.09 \\
(0.02)\end{array}$ & $\begin{array}{c}0.12 \\
(0.03)\end{array}$ & $\begin{array}{c}0.14 \\
(0.05)\end{array}$ & $\begin{array}{c}0.10 \\
(0.03)\end{array}$ \\
\hline Capital ratio & $\begin{array}{c}0.09 \\
(0.07)\end{array}$ & $\begin{array}{c}0.07 \\
(0.03)\end{array}$ & $\begin{array}{c}0.09 \\
(0.08)\end{array}$ & $\begin{array}{c}0.07 \\
(0.02)\end{array}$ & $\begin{array}{c}0.12 \\
(0.01)\end{array}$ \\
\hline Deposit ratio & $\begin{array}{c}0.43 \\
(0.14)\end{array}$ & $\begin{array}{c}0.49 \\
(0.08)\end{array}$ & $\begin{array}{c}0.47 \\
(0.09)\end{array}$ & $\begin{array}{c}0.58 \\
(0.06)\end{array}$ & $\begin{array}{c}0.43 \\
(0.06)\end{array}$ \\
\hline ROA & $\begin{array}{c}1.0 \\
(2.0)\end{array}$ & $\begin{array}{c}1.1 \\
(0.4)\end{array}$ & $\begin{array}{c}1.7 \\
(0.7)\end{array}$ & $\begin{array}{c}0.8 \\
(0.6)\end{array}$ & $\begin{array}{c}1.5 \\
(0.7)\end{array}$ \\
\hline ROE & $\begin{array}{c}12.9 \\
(11.5)\end{array}$ & $\begin{array}{l}16.6 \\
(6.8)\end{array}$ & $\begin{array}{l}19.9 \\
(7.9)\end{array}$ & $\begin{array}{l}11.6 \\
(9.1)\end{array}$ & $\begin{array}{l}12.3 \\
(6.3)\end{array}$ \\
\hline Commercial Credit & $\begin{array}{c}0.34 \\
(0.16)\end{array}$ & $\begin{array}{c}0.34 \\
(0.10)\end{array}$ & $\begin{array}{c}0.28 \\
(0.06)\end{array}$ & $\begin{array}{c}0.29 \\
(0.05)\end{array}$ & $\begin{array}{c}0.23 \\
(0.06)\end{array}$ \\
\hline Market share & $\begin{array}{c}0.06 \\
(0.07)\end{array}$ & $\begin{array}{c}0.14 \\
(0.03)\end{array}$ & $\begin{array}{c}0.16 \\
(0.06)\end{array}$ & $\begin{array}{c}0.11 \\
(0.03)\end{array}$ & $\begin{array}{c}0.15 \\
(0.03)\end{array}$ \\
\hline Commercial Loan P & Compositior & & & & \\
\hline Agriculture & 4 & 7 & 5 & 8 & 6 \\
\hline Construction & 9 & 9 & 16 & 9 & 6 \\
\hline Manufacturing & 19 & 21 & 24 & 24 & 26 \\
\hline Retail & 38 & 35 & 31 & 36 & 42 \\
\hline Services & 22 & 18 & 15 & 15 & 12 \\
\hline Other Sectors & 8 & 10 & 8 & 9 & 8 \\
\hline
\end{tabular}


Table IAII

Summary Statistics Monthly Data by Firms’ Yield

This table reports average loan margins for high and low yield firms. A firm-bank-month observation is classified as having high (low) yield if the interest rate the firm pays on its loan is above (below) the average loan interest rate, weighted by loan volume, paid by all firms across all loans in the given month.

\begin{tabular}{lcccccc}
\hline \hline & \multicolumn{3}{c}{ High-yield firms } & \multicolumn{3}{c}{ Low-yield firms } \\
& Mean & Median & St. Dev & Mean & Median & St. Dev \\
\cline { 2 - 7 } & $(1)$ & $(2)$ & $(3)$ & $(4)$ & $(5)$ & $(6)$ \\
\hline Loan Volume & 842 & 302 & 1,692 & 4,908 & 3,332 & 4,697 \\
Loan Maturity & 33.5 & 36.0 & 19.6 & 32.4 & 24.0 & 28.8 \\
Loan Collateral & 0.24 & 0.00 & 0.43 & 0.45 & 0.23 & 0.83 \\
Loan Rate & 16.2 & 16.1 & 7.4 & 8.2 & 9.3 & 2.1 \\
Loan Default & 0.08 & 0.00 & 0.27 & 0.03 & 0.00 & 0.17 \\
\hline
\end{tabular}




\section{Table IAIII}

Characteristics of Firms Borrowing from Foreign Banks and from the Largest Domestic Bank

This table reports the estimates from OLS regressions for the period 2001 to 2015. Each observation represents a firm-year pair. The sample is limited to firms borrowing from foreign banks and the largest domestic bank. bank-country is an indicator variable that is equal to one if a bank is from country, where country stands for the U.S., the U.K., and the Euro Area (the omitted category corresponds to the largest Mexican bank). The dependent variables are the total bank loan volume and total assets (both in logs) of a firm in a given year. All regressions include fixed effects at the state*industry*year level. Standard errors are clustered at the year and state*industry levels and are reported in parentheses. $*, * * * * *$ significant at the $10 \%, 5 \%$ and $1 \%$ level respectively.

\begin{tabular}{lcc}
\hline \hline & Loan Volume (logs) & Total Assets (logs) \\
\cline { 2 - 3 } & $(1)$ & $(2)$ \\
\hline bank-us & 0.17 & 0.25 \\
& $(0.40)$ & $(0.97)$ \\
bank-uk & 0.70 & 0.66 \\
& $(0.45)$ & $(1.67)$ \\
bank-euro & 0.31 & 0.59 \\
& $(0.26)$ & $(0.91)$ \\
Observations & & 13,287 \\
$\mathrm{R}^{2}$ & 642,309 & 0.88 \\
\hline
\end{tabular}




\section{Table IAIV}

\section{Characteristics of firms in Orbis and Rest of Firms}

This table reports the credit margins of the borrowers that are in the Orbis sample and of those that are not in it. The first two columns report means and standard-deviations (in parentheses) of characteristics of firms present in the loan-level data set, depending on whether they are in the Orbis data set. The third column presents the mean difference of each variable between the two groups (with its $t$-statistic in parentheses). Firm age is measured in years; loan volume is measured in thousands of Mexican pesos in January 2008 prices; loan maturity is the average duration of the loans; loan collateral is the fraction of loans guaranteed by firm assets; loan rate is the interest rate charged by banks in percent; and loan default is the fraction of loans in arrears for more than 90 days.

\begin{tabular}{lccc}
\hline \hline & Orbis & Non-Orbis & $\begin{array}{c}\text { Difference } \\
\text { (t-stats) }\end{array}$ \\
\cline { 2 - 4 } & $(1)$ & $(2)$ & $(3)$ \\
\hline firm age & 15.5 & 13.9 & 1.8 \\
loan volume (logs) & $(10.0)$ & $(13.9)$ & $(34.7)$ \\
& 16.0 & 15.0 & 1.0 \\
loan maturity (months) & $(2.4)$ & $(2.7)$ & $(118.3)$ \\
& 30.0 & 34.2 & -4.2 \\
loan collateral & $(28.5)$ & $(28.1)$ & $(-38.8)$ \\
& 0.30 & 0.27 & 0.03 \\
loan rate & $(0.42)$ & $(0.5)$ & $(15.8)$ \\
& 13.8 & 15.1 & 1.3 \\
loan default & $(5.1)$ & $(5.4)$ & $(-63.7)$ \\
& 0.07 & 0.13 & -0.05 \\
& $(0.23)$ & $(0.3)$ & $(-45.4)$ \\
\hline
\end{tabular}




\section{Table IAV}

\section{Probability that a Firm Switches Banks}

This table reports the estimates from OLS regressions for the period 2001 to 2015. Observations are at the firm-year level. The dependent variable is an indicator variable that equals one if the largest bank from which the firm borrows changes from year $t$ to $t+1$. Domestic bank is an indicator variable that is equal to one if the main bank in year $t$ is domestic. \# of bank relations is the number of banks from which the firm is borrows in year $t$. Loan maturity is the average loan maturity of the firm in year $y$. Loan volume is the total outstanding amount of loans of the firm in year t. Large firm is a dummy variable indicating whether the firm had more than 50 workers, which proxies for larger firms. Standard errors are clustered at the period and bank-state levels and are presented in parentheses.

\begin{tabular}{lc}
\hline \hline & $\mathrm{I}\left(\right.$ switching $\left._{\mathrm{i}, \mathrm{t}}\right)$ \\
\hline domestic bank & 0.00 \\
number of bank relations $(\log )$ & $(0.01)$ \\
& $0.30^{* * *}$ \\
loan volume (logs) & $(0.03)$ \\
& $-0.00^{*}$ \\
loan maturity (logs) & $(0.00)$ \\
& $-0.02^{* * *}$ \\
Large firm & $(0.01)$ \\
& -0.00 \\
Sector F.E. & $(0.01)$ \\
Period F.E. & \\
& Yes \\
Observations & Yes \\
$\mathrm{R}^{2}$ & $5,630,290$ \\
\hline
\end{tabular}




\section{Table IAVI}

Impact of International Monetary Policies on Domestic Loan Volume (June 2001 - Nov 2009)

This table reports the estimates from OLS regressions for the period June 2001 to November 2009. Observations are at the firm-bank-month level. The dependent variable is the firm's loan volume from a given bank in a given month. intrate-countryr is the residual of the policy rate of country, where country stands for U.S., U.K., Euro Area, or Mexico. bank-country is a dummy variable that equals to one if the bank is from country. Other controls are listed in Section II of the main article. Fixed effects already absorbed by other fixed effects are indicated by ". ". Standard errors clustered at the period and bank-industry levels are reported in parentheses, where a period is a month. ***,*** significant at the $10 \%, 5 \%$ and $1 \%$ level respectively.

\begin{tabular}{|c|c|c|c|c|}
\hline & $\overline{(1)}$ & $\overline{(2)}$ & $(3)$ & (4) \\
\hline intrate-usr & $\begin{array}{l}-0.44^{*} \\
(0.24)\end{array}$ & & & \\
\hline intrate-usr * bank-us & $\begin{array}{c}-1.08 * * \\
(0.54)\end{array}$ & $\begin{array}{c}-1.53 * * \\
(0.60)\end{array}$ & $\begin{array}{c}-1.69 * * * \\
(0.50)\end{array}$ & $\begin{array}{c}-2.06^{* * *} \\
(0.78)\end{array}$ \\
\hline intrate-ukr & $\begin{array}{l}0.85 * * \\
(0.39)\end{array}$ & & & \\
\hline intrate-ukr * bank-uk & $\begin{array}{c}-2.65 * * * \\
(0.95)\end{array}$ & $\begin{array}{c}-4.81 * * * \\
(1.22)\end{array}$ & $\begin{array}{c}-5.60 * * * \\
(1.08)\end{array}$ & $\begin{array}{c}-5.90 * * * \\
(1.82)\end{array}$ \\
\hline intrate-euror & $\begin{array}{l}1.29 * * \\
(0.54)\end{array}$ & & & \\
\hline intrate-euror * bank-euro & $\begin{array}{c}0.89 \\
(0.94)\end{array}$ & $\begin{array}{c}0.83 \\
(1.08)\end{array}$ & $\begin{array}{c}0.74 \\
(0.88)\end{array}$ & $\begin{array}{c}0.77 \\
(1.43)\end{array}$ \\
\hline intrate-mexr & $\begin{array}{c}-0.91 * * * \\
(0.30)\end{array}$ & & & \\
\hline intrate-mexr * bank-mex & $\begin{array}{l}-0.18 \\
(0.39)\end{array}$ & $\begin{array}{c}0.63 \\
(0.84)\end{array}$ & $\begin{array}{c}0.39 \\
(0.65)\end{array}$ & $\begin{array}{c}0.74 \\
(1.08)\end{array}$ \\
\hline Firm*Bank F.E. & Yes & Yes & Yes & Yes \\
\hline State*Industry*Period F.E. & No & Yes & Yes & - \\
\hline Firm*Period F.E. & No & No & No & Yes \\
\hline Firms borrowing from more than 1 bank & No & No & Yes & Yes \\
\hline $\begin{array}{l}\text { Observations } \\
\mathrm{R}^{2}\end{array}$ & $\begin{array}{c}4,309,232 \\
0.01\end{array}$ & $\begin{array}{c}4,309,232 \\
0.03\end{array}$ & $\begin{array}{c}1,367,706 \\
0.05\end{array}$ & $\begin{array}{c}1,367,706 \\
0.50\end{array}$ \\
\hline
\end{tabular}




\section{Table IAVII}

\section{Impact of International Monetary Policies on Banks’ Balance Sheet Variables}

This table reports the estimates from OLS regressions for the period June 2001 to December 2015. Observations are at the bank-month level. Assets are the total assets (in logs) of a bank in a given month. Overdue credit is the ratio of credit in arrears to total credit of a bank in a given month. Liabilities are the total liabilities (in logs) of a bank in a given month. Short-term liabilities are the short-term and immediate liabilities (in logs) in a given month. Foreign Liabilities are the liabilities from foreign banks and central banks (in logs) in a given month. intrate-fgnr is the residual of the interest rate of the country in which the foreign bank is headquartered, on its GDP and CPI growth. fgn-bank is a foreign bank indicator. intrate-mexr is the residual of policy rate of Mexico. qe-fgn is the QE of the foreign country in which the bank is headquartered in, with QE measured as the ratio of the annual change in central bank assets to GDP. Controls include linear time trends for banks headquartered in Mexico, the Eurozone, U.K., and U.S. Additional control variables are listed in Section II of the main article. Standard errors clustered at the period level are in parentheses, where a period is a month. $* * *, * * *$ significant at the $10 \%, 5 \%$ and $1 \%$ level respectively.

\begin{tabular}{lccccc}
\hline \hline & Assets & $\begin{array}{c}\text { Overdue } \\
\text { Credit }\end{array}$ & Liabilities & $\begin{array}{c}\text { Short-term } \\
\text { Liabilities }\end{array}$ & $\begin{array}{c}\text { Foreign } \\
\text { Liabilities }\end{array}$ \\
\cline { 2 - 6 } & $(1)$ & $(2)$ & $(3)$ & $(4)$ & $(5)$ \\
\hline \multirow{2}{*}{ intrate-fgnr* bank-fgn } & $-1.55^{*}$ & $-0.36^{* * *}$ & $-2.52^{* * *}$ & -8.10 & $-6.09^{* * *}$ \\
& $(0.79)$ & $(0.09)$ & $(0.93)$ & $(6.05)$ & $(1.80)$ \\
intrate-mexr * bank-mex & -0.45 & 0.06 & -0.21 & 2.69 & $-3.12^{*}$ \\
& $(0.70)$ & $(0.10)$ & $(0.75)$ & $(3.28)$ & $(1.76)$ \\
qe-fgn * bank-fgn & $1.62^{* * *}$ & $0.13^{* * *}$ & $1.51^{* * *}$ & 1.85 & $1.87^{* *}$ \\
& $(0.25)$ & $(0.03)$ & $(0.27)$ & $(1.27)$ & $(0.73)$ \\
Period F.E. & & & & & \\
Bank F.E. & Yes & Yes & Yes & Yes & Yes \\
Observations & Yes & Yes & Yes & Yes & Yes \\
$\mathrm{R}^{2}$ & 2,627 & 2,591 & 2,627 & 2,593 & 2,593 \\
& 0.97 & 0.16 & 0.96 & 0.80 & 0.85 \\
\hline
\end{tabular}




\section{Table IAVIII}

\section{Impact of International Monetary Policies on Domestic Credit Margins of Firms in Tradeable and Non-Tradeable Sectors}

This table reports the estimates from OLS regressions for the period June 2001 to December 2015. Observations are at the firm-bank-month level. Trade is an indicator of tradable industries following the classification outlined by Amir and Mian (2012), Nontrade contains the remaining industries. The dependent variables are: a firm's log loan volume, maturity, collateral rate, loan interest rate and default rate at $t+12$ with a given bank in a given month. intrate-countryr is the residual of the policy rate of country, where country stands for U.S., U.K., Euro Area, or Mexico. qe-country is the ratio of the annual real change in central bank assets to GDP of country. country-bank is a dummy variable indicating whether the bank is from country. Other controls are listed in Section II of the main article. Standard errors are reported in parentheses and are clustered at the period and bank-industry level, where a period is a month. *,**,*** significant at the $10 \%, 5 \%$ and $1 \%$ level respectively.

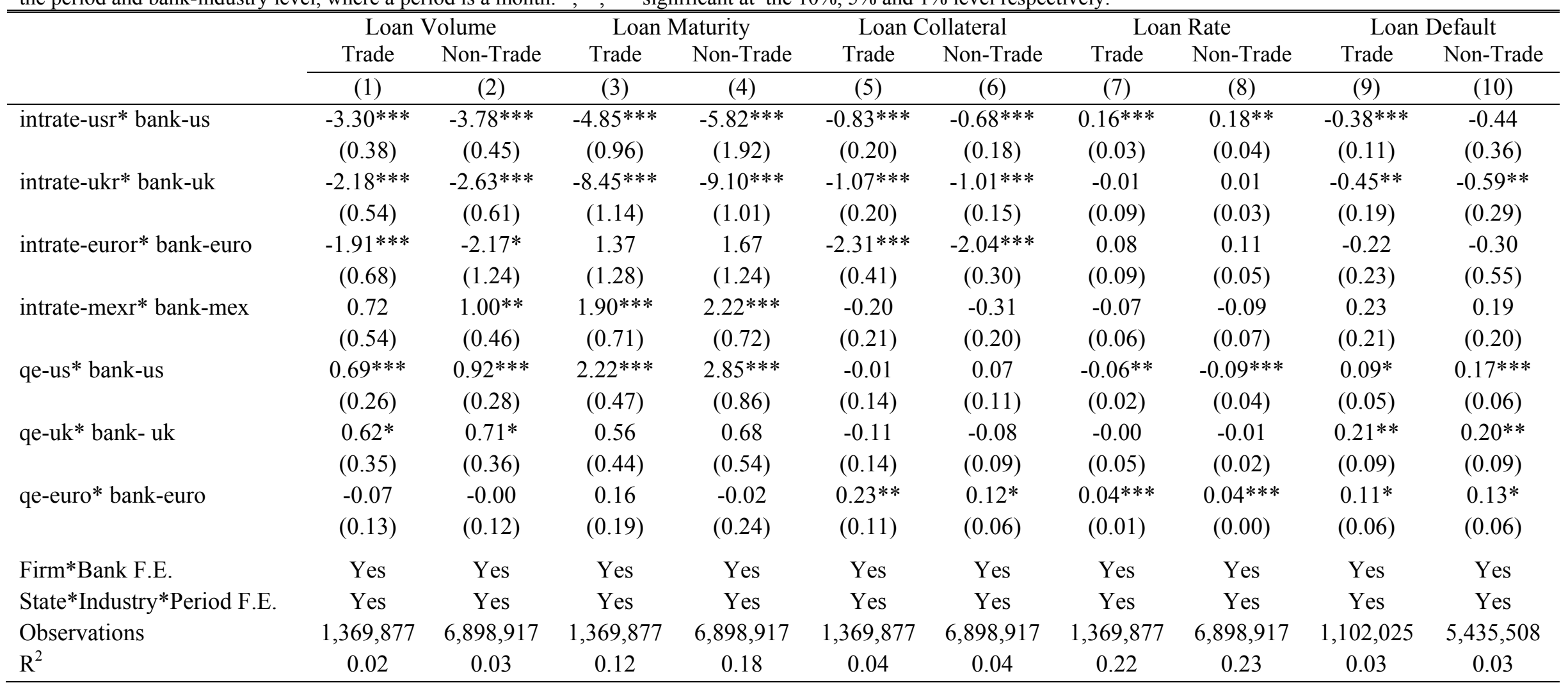




\section{Table IAIX}

Impact of International Monetary Policies on Domestic Credit Margins of Firms from Northern and Southern States

This table reports the estimates from OLS regressions for the period June 2001 to December 2015. Observations are at the firm-bank-month level. North is an indicator of northern states according to the classification of the National Statistics Agency (INEGI) and includes all Northeast, Northwest and Center-North states, whereas South comprises all the remaining states. The dependent variables are the firm's log loan volume, maturity, collateral rate, loan interest rate and default rate at $t+12$ with a given bank in a given month. intrate-countryr is the residual of the policy rate of country, where country stands for U.S., U.K., Euro Area, or Mexico. qe-country is the ratio of the annual change in central bank assets to GDP of country. bank- country is a dummy variable indicating whether that bank is from country. Other controls are listed in Section II of the main article. Standard errors are reported in parentheses and are clustered at the period and bank-industry levels, where a period is a month. $* * *, * * *$ significant at the $10 \%, 5 \%$ and $1 \%$ level respectively.

\begin{tabular}{|c|c|c|c|c|c|c|c|c|c|c|}
\hline & \multicolumn{2}{|c|}{ Loan Volume } & \multicolumn{2}{|c|}{ Loan Maturity } & \multicolumn{2}{|c|}{ Loan Collateral } & \multicolumn{2}{|c|}{ Loan Rate } & \multicolumn{2}{|c|}{ Loan Default } \\
\hline & North & South & North & South & North & South & North & South & North & South \\
\hline & $(1)$ & $(2)$ & (3) & (4) & $(5)$ & $(6)$ & (7) & $(8)$ & (9) & $(10)$ \\
\hline intrate-usr $*$ bank-us & $\begin{array}{c}-3.21 * * * \\
(0.76)\end{array}$ & $\begin{array}{c}-3.95 * * * \\
(0.51)\end{array}$ & $\begin{array}{c}-6.03 * * * \\
(1.44)\end{array}$ & $\begin{array}{c}-5.41 * * * \\
(1.81)\end{array}$ & $\begin{array}{c}-0.56^{* * *} \\
(0.20)\end{array}$ & $\begin{array}{c}-0.79 * * * \\
(0.18)\end{array}$ & $\begin{array}{c}0.16^{* *} \\
(0.09)\end{array}$ & $\begin{array}{c}0.19 * * \\
(0.11)\end{array}$ & $\begin{array}{c}-0.67 * * \\
(0.26)\end{array}$ & $\begin{array}{l}-0.29 \\
(0.34)\end{array}$ \\
\hline intrate-ukr * bank-uk & $\begin{array}{c}-2.26 * * * \\
(0.70)\end{array}$ & $\begin{array}{c}-2.75 * * * \\
(0.69)\end{array}$ & $\begin{array}{c}-8.79 * * * \\
(0.89)\end{array}$ & $\begin{array}{c}-9.13 * * * \\
(0.93)\end{array}$ & $\begin{array}{c}-1.03 * * * \\
(0.16)\end{array}$ & $\begin{array}{c}-1.03 * * * \\
(0.15)\end{array}$ & $\begin{array}{c}0.00 \\
(0.01)\end{array}$ & $\begin{array}{c}0.01 \\
(0.02)\end{array}$ & $\begin{array}{c}-0.78 * * * \\
(0.21)\end{array}$ & $\begin{array}{l}-0.43 \\
(0.31)\end{array}$ \\
\hline intrate-euror $*$ bank- euro & $\begin{array}{c}-2.74 * * * \\
(0.89)\end{array}$ & $\begin{array}{l}-1.95 \\
(1.36)\end{array}$ & $\begin{array}{c}1.35 \\
(1.31)\end{array}$ & $\begin{array}{c}1.73 \\
(1.07)\end{array}$ & $\begin{array}{c}-2.23 * * * \\
(0.26)\end{array}$ & $\begin{array}{c}-2.04 * * * \\
(0.32)\end{array}$ & $\begin{array}{c}0.12 \\
(0.08)\end{array}$ & $\begin{array}{c}0.10 \\
(0.09)\end{array}$ & $\begin{array}{l}-0.43 \\
(0.38)\end{array}$ & $\begin{array}{l}-0.18 \\
(0.54)\end{array}$ \\
\hline intrate-mexr * bank-mex & $\begin{array}{c}0.81 \\
(0.75)\end{array}$ & $\begin{array}{c}1.05 * * * \\
(0.38)\end{array}$ & $\begin{array}{c}2.11 * * * \\
(0.51)\end{array}$ & $\begin{array}{c}2.21 * * \\
(0.93)\end{array}$ & $\begin{array}{l}-0.10 \\
(0.26)\end{array}$ & $\begin{array}{c}-0.44^{* *} \\
(0.20)\end{array}$ & $\begin{array}{l}-0.08 \\
(0.11)\end{array}$ & $\begin{array}{l}-0.08 \\
(0.13)\end{array}$ & $\begin{array}{c}0.27 \\
(0.18)\end{array}$ & $\begin{array}{c}0.14 \\
(0.22)\end{array}$ \\
\hline qe-us $*$ bank-us & $\begin{array}{c}0.95 * * * \\
(0.32)\end{array}$ & $\begin{array}{c}0.85 * * * \\
(0.26)\end{array}$ & $\begin{array}{c}2.52 * * * \\
(0.72)\end{array}$ & $\begin{array}{c}2.82 * * * \\
(0.83)\end{array}$ & $\begin{array}{c}0.02 \\
(0.14)\end{array}$ & $\begin{array}{c}0.08 \\
(0.10)\end{array}$ & $\begin{array}{c}-0.07 * * * \\
(0.02)\end{array}$ & $\begin{array}{c}-0.09 * * * \\
(0.03)\end{array}$ & $\begin{array}{c}0.13 \\
(0.09)\end{array}$ & $\begin{array}{c}0.16^{* * *} \\
(0.05)\end{array}$ \\
\hline qe-uk * bank-uk & $\begin{array}{l}0.81 * \\
(0.50)\end{array}$ & $\begin{array}{l}0.66^{*} \\
(0.37)\end{array}$ & $\begin{array}{c}0.62 \\
(0.46)\end{array}$ & $\begin{array}{c}0.68 \\
(0.55)\end{array}$ & $\begin{array}{l}-0.10 \\
(0.10)\end{array}$ & $\begin{array}{l}-0.08 \\
(0.09)\end{array}$ & $\begin{array}{l}-0.01 \\
(0.03)\end{array}$ & $\begin{array}{l}-0.01 \\
(0.02)\end{array}$ & $\begin{array}{c}0.16 \\
(0.10)\end{array}$ & $\begin{array}{c}0.22 * * \\
(0.09)\end{array}$ \\
\hline qe-euro $*$ bank-euro & $\begin{array}{c}0.16 \\
(0.31)\end{array}$ & $\begin{array}{l}-0.10 \\
(0.13)\end{array}$ & $\begin{array}{c}0.08 \\
(0.29)\end{array}$ & $\begin{array}{l}-0.02 \\
(0.21)\end{array}$ & $\begin{array}{c}0.11 \\
(0.06)\end{array}$ & $\begin{array}{c}0.15^{* *} \\
(0.07)\end{array}$ & $\begin{array}{c}0.03 * * * \\
(0.00)\end{array}$ & $\begin{array}{c}0.04 * * * \\
(0.00)\end{array}$ & $\begin{array}{c}0.10 \\
(0.09)\end{array}$ & $\begin{array}{c}0.14 * * \\
(0.06)\end{array}$ \\
\hline Firm*Bank F.E. & Yes & Yes & Yes & Yes & Yes & Yes & Yes & Yes & Yes & Yes \\
\hline State*Industry*Period F.E. & Yes & Yes & Yes & Yes & Yes & Yes & Yes & Yes & Yes & Yes \\
\hline Observations & $3,034,567$ & $5,234,227$ & $3,034,567$ & $5,234,227$ & $3,034,567$ & $5,234,227$ & $3,034,567$ & $5,234,227$ & $2,428,606$ & $4,108,927$ \\
\hline $\mathrm{R}^{2}$ & 0.03 & 0.03 & 0.15 & 0.18 & 0.04 & 0.03 & 0.21 & 0.24 & 0.03 & 0.03 \\
\hline
\end{tabular}




\section{Table IAX}

\section{Impact of International Monetary Policies on Loan Volume Controlling for Bank Characteristics}

This table reports the estimates from OLS regressions for the period June 2001 to December 2015. Observations are at the firm-bank-month level. All regressions control for time-varying bank size (in logs) as well as the liquidity and capital ratio in a given bank at a given month. The dependent variable is the firm's volume of loans, in logs with a bank in a given month. intrate-countryr is the residual of policy rate of country, where country stands for U.S., U.K., Euro Area, or Mexico. qecountry is the ratio of the annual real change in central bank assets to GDP of country. bank-country is a dummy variable indicating whether that bank is from country. Other controls are listed in Section II of the main article. Fixed effects already absorbed by other fixed effects are indicated by "..". Standard errors are reported in parentheses and are clustered at the period and bank-industry level, where a period is a month. *,**,** significant at the $10 \%, 5 \%$ and $1 \%$ level respectively.

\begin{tabular}{|c|c|c|c|c|}
\hline & $(1)$ & $(2)$ & (3) & $(4)$ \\
\hline intrate-usr & $\begin{array}{l}-0.27^{*} \\
(0.16)\end{array}$ & & & \\
\hline intrate-usr $*$ bank-us & $\begin{array}{c}-2.83 * * * \\
(0.34)\end{array}$ & $\begin{array}{c}-3.39 * * * \\
(0.37)\end{array}$ & $\begin{array}{c}-2.92 * * * \\
(0.33)\end{array}$ & $\begin{array}{c}-3.04 * * * \\
(0.50)\end{array}$ \\
\hline intrate-ukr & $\begin{array}{l}-0.08 \\
(0.31)\end{array}$ & & & \\
\hline intrate-ukr * bank-uk & $\begin{array}{c}-1.15 * * \\
(0.48)\end{array}$ & $\begin{array}{c}-2.49 * * * \\
(0.61)\end{array}$ & $\begin{array}{c}-2.31 * * * \\
(0.45)\end{array}$ & $\begin{array}{c}-2.67 * * * \\
(0.70)\end{array}$ \\
\hline intrate-euror & $\begin{array}{c}1.84 * * * \\
(0.62)\end{array}$ & & & \\
\hline intrate-euror $*$ bank-euro & $\begin{array}{c}-2.32 * * * \\
(0.81)\end{array}$ & $\begin{array}{l}-1.90 * \\
(1.04)\end{array}$ & $\begin{array}{c}-1.14 * * \\
(0.53)\end{array}$ & $\begin{array}{l}-0.64 \\
(0.82)\end{array}$ \\
\hline intrate-mexr & $\begin{array}{c}-0.78 * * * \\
(0.19)\end{array}$ & & & \\
\hline intrate-mexr $*$ bank-mex & $\begin{array}{c}0.00 \\
(0.32)\end{array}$ & $\begin{array}{c}0.80 \\
(0.50)\end{array}$ & $\begin{array}{l}-0.03 \\
(0.51)\end{array}$ & $\begin{array}{l}-0.01 \\
(0.80)\end{array}$ \\
\hline qe-us & $\begin{array}{c}-0.46^{* * *} \\
(0.11)\end{array}$ & & & \\
\hline qe-us * bank-us & $\begin{array}{c}0.64 * * * \\
(0.25)\end{array}$ & $\begin{array}{c}0.98 * * * \\
(0.25)\end{array}$ & $\begin{array}{c}0.94 * * * \\
(0.19)\end{array}$ & $\begin{array}{c}1.01 * * * \\
(0.28)\end{array}$ \\
\hline qe-uk & $\begin{array}{l}-0.08 \\
(0.11)\end{array}$ & & & \\
\hline qe-uk * bank-uk & $\begin{array}{c}0.59 * * * \\
(0.18)\end{array}$ & $\begin{array}{l}0.65^{*} \\
(0.34)\end{array}$ & $\begin{array}{l}0.53 * \\
(0.31)\end{array}$ & $\begin{array}{c}0.45 \\
(0.47)\end{array}$ \\
\hline qe-euro & $\begin{array}{l}0.13^{*} \\
(0.08)\end{array}$ & & & \\
\hline qe-euro $*$ bank-euro & $\begin{array}{c}0.39 * * * \\
(0.12)\end{array}$ & $\begin{array}{c}0.13 \\
(0.15)\end{array}$ & $\begin{array}{c}0.17 \\
(0.12)\end{array}$ & $\begin{array}{c}0.13 \\
(0.19)\end{array}$ \\
\hline Firm*Bank F.E. & Yes & Yes & Yes & Yes \\
\hline State*Industry*Period F.E. & No & Yes & Yes & - \\
\hline Firm*Period F.E. & No & No & No & Yes \\
\hline Firms borrowing from more than 1 bank & No & No & Yes & Yes \\
\hline $\begin{array}{l}\text { Observations } \\
\mathrm{R}^{2}\end{array}$ & $\begin{array}{c}8,268,794 \\
0.01\end{array}$ & $\begin{array}{c}8,268,794 \\
0.03\end{array}$ & $\begin{array}{c}3,020,617 \\
0.04\end{array}$ & $\begin{array}{c}3,020,617 \\
0.48\end{array}$ \\
\hline
\end{tabular}




\section{Table IAXI}

\section{Impact of Instrumented Fed Fund Rates on Domestic Loan Volume}

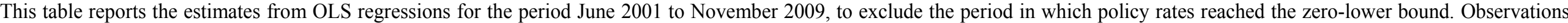

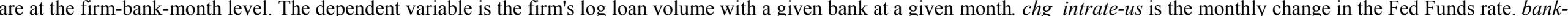

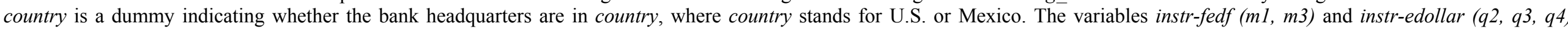

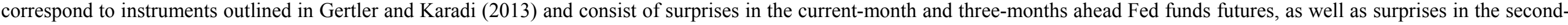

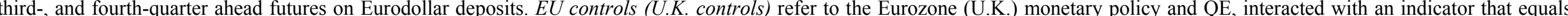

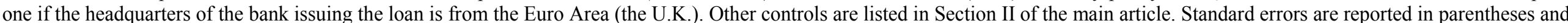
are clustered at the period and bank-industry levels, where a period is a month. *,**,*** significant at the $10 \%, 5 \%$ and $1 \%$ level respectively.

\begin{tabular}{|c|c|c|c|c|c|c|c|c|c|c|c|c|}
\hline & (1) & (2) & (3) & (4) & (5) & (6) & $(7)$ & $(8)$ & (9) & $(10)$ & $(11)$ & $(12)$ \\
\hline chg_intrate-us* bank-us & $\begin{array}{c}-0.06^{* * * *} \\
(0.01)\end{array}$ & $\begin{array}{c}-0.10 * * * \\
(0.01)\end{array}$ & & & & & & & & & & \\
\hline instr-fedf $f_{\mathrm{m} 1} *$ bank-us & & & $\begin{array}{c}-0.05^{* * *} \\
(0.01)\end{array}$ & $\begin{array}{c}-0.06 * * * \\
(0.01)\end{array}$ & & & & & & & & \\
\hline instr-fedf $\mathrm{m}_{3} *$ bank-us & & & & & $\begin{array}{c}-0.12 * * * \\
(0.03)\end{array}$ & $\begin{array}{c}-0.13 * * * \\
(0.03)\end{array}$ & & & & & & \\
\hline instr-edollar $\mathrm{r}_{\mathrm{q} 2} *$ bank-us & & & & & & & $\begin{array}{c}-0.16^{* * *} \\
(0.02)\end{array}$ & $\begin{array}{c}-0.19 * * * \\
(0.02)\end{array}$ & & & & \\
\hline instr-edollar ${ }_{\mathrm{q} 3} *$ bank-us & & & & & & & & & $\begin{array}{c}-0.14 * * * \\
(0.02)\end{array}$ & $\begin{array}{c}-0.18 * * * \\
(0.02)\end{array}$ & & \\
\hline instr-edollar $\mathrm{r}_{\mathrm{q} 4} *$ bank-us & & & & & & & & & & & $\begin{array}{c}-0.10 * * * \\
(0.02)\end{array}$ & $\begin{array}{c}-0.14 * * * \\
(0.02)\end{array}$ \\
\hline intrate-mexr* bank-mex & $\begin{array}{c}0.10 \\
(0.25)\end{array}$ & $\begin{array}{c}0.05 \\
(0.30)\end{array}$ & $\begin{array}{c}0.13 \\
(0.24)\end{array}$ & $\begin{array}{c}0.17 \\
(0.28)\end{array}$ & $\begin{array}{c}0.13 \\
(0.24)\end{array}$ & $\begin{array}{c}0.18 \\
(0.28)\end{array}$ & $\begin{array}{c}0.13 \\
(0.24)\end{array}$ & $\begin{array}{c}0.18 \\
(0.28)\end{array}$ & $\begin{array}{c}0.13 \\
(0.24)\end{array}$ & $\begin{array}{c}0.18 \\
(0.28)\end{array}$ & $\begin{array}{c}0.13 \\
(0.24)\end{array}$ & $\begin{array}{c}0.17 \\
(0.28)\end{array}$ \\
\hline EU controls & No & Yes & No & Yes & No & Yes & No & Yes & No & Yes & No & Yes \\
\hline U.K. controls & No & Yes & No & Yes & No & Yes & No & Yes & No & Yes & No & Yes \\
\hline Firm*Bank F.E. & Yes & Yes & Yes & Yes & Yes & Yes & Yes & Yes & Yes & Yes & Yes & Yes \\
\hline State*Industry*Period FE & Yes & Yes & Yes & Yes & Yes & Yes & Yes & Yes & Yes & Yes & Yes & Yes \\
\hline Observations & $4,309,232$ & $4,309,232$ & $4,309,232$ & $4,309,232$ & $4,309,232$ & $4,309,232$ & $4,309,232$ & $4,309,232$ & $4,309,232$ & $4,309,232$ & $4,309,232$ & $4,309,232$ \\
\hline $\mathrm{R}^{2}$ & 0.03 & 0.04 & 0.03 & 0.04 & 0.03 & 0.04 & 0.03 & 0.04 & 0.03 & 0.04 & 0.03 & 0.04 \\
\hline
\end{tabular}




\section{Table IAXII}

Impact of International Monetary Policies on Domestic Credit Margins (Five Largest Banks)

This table reports the estimates from OLS regressions for the period June 2001 to December 2015. Observations are at the firm-bank-month level. The sample is restricted to loans from the five largest banks by total commercial credit. Dependent variables are the firm's log loan volume, log maturity, collateral rate, loan interest rate and default rate 12-months ahead with a given bank in a given month. intrate-countryr is the residual of the policy rate of country, where country stands for U.S., U.K., Euro Area, or Mexico. qe-country is the ratio of the annual real change in central bank assets to GDP of country. country-bank is a dummy variable indicating whether bank headquarters are in country, where country stands for U.S., U.K., Euro Area or Mexico. Other controls are listed in Section II of the main article. All regressions include fixed effects at the firm-bank level. Columns (2), (4), (6), (8) and (10) include state*industry*period

fixed rffects. Standard errors are reported in parentheses and are clustered at the period and bank-industry level. *,**,*** significant at the $10 \%, 5 \%$ and $1 \%$ level respectively.

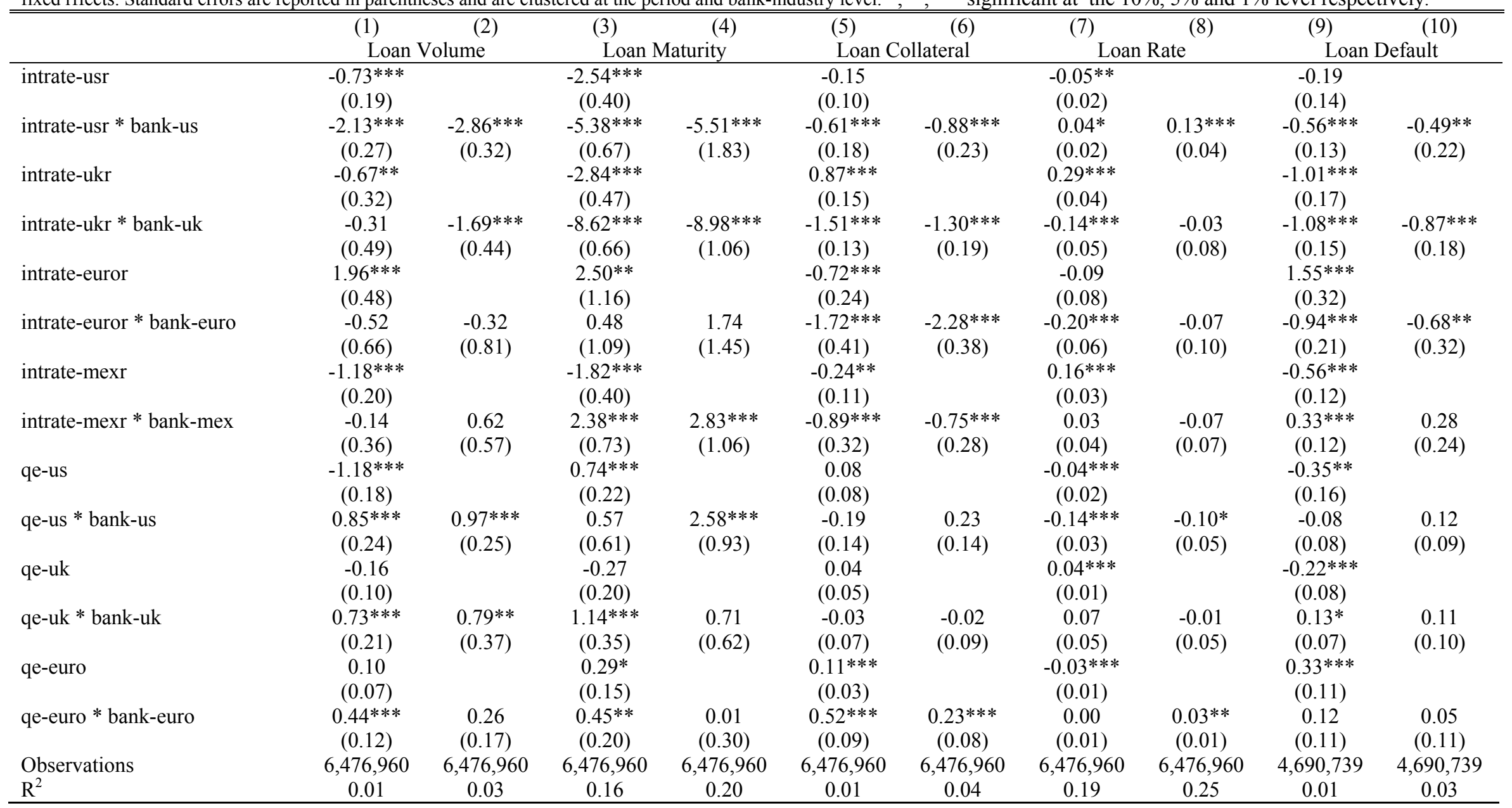


Table IAXIII

Impact of International Monetary Policies on Credit Margins (Controlling for Sovereign Credit Default Swaps of the U.K., U.S., and Eurozone)

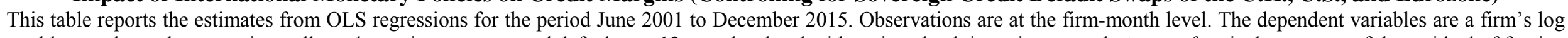

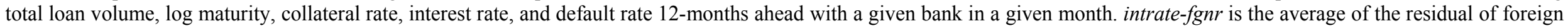
overnight rates, weighted by the firm's share of loans from U.S., U.K., and Eurozone banks. share-fgn is the one-quarter lagged share of loans from foreign banks. intrate-mexr is the

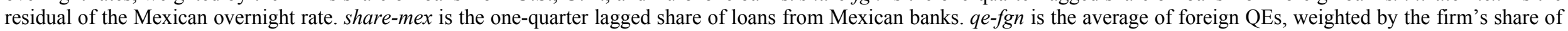
loans from U.S., U.K., or Eurozone banks. $c d s$ is the average level of foreign sovereign credit default swaps, weighted by the firm's share of loans from U.S., U.K., and Eurozone

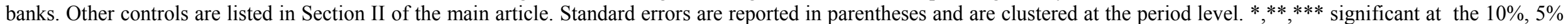
and $1 \%$ level respectively. 


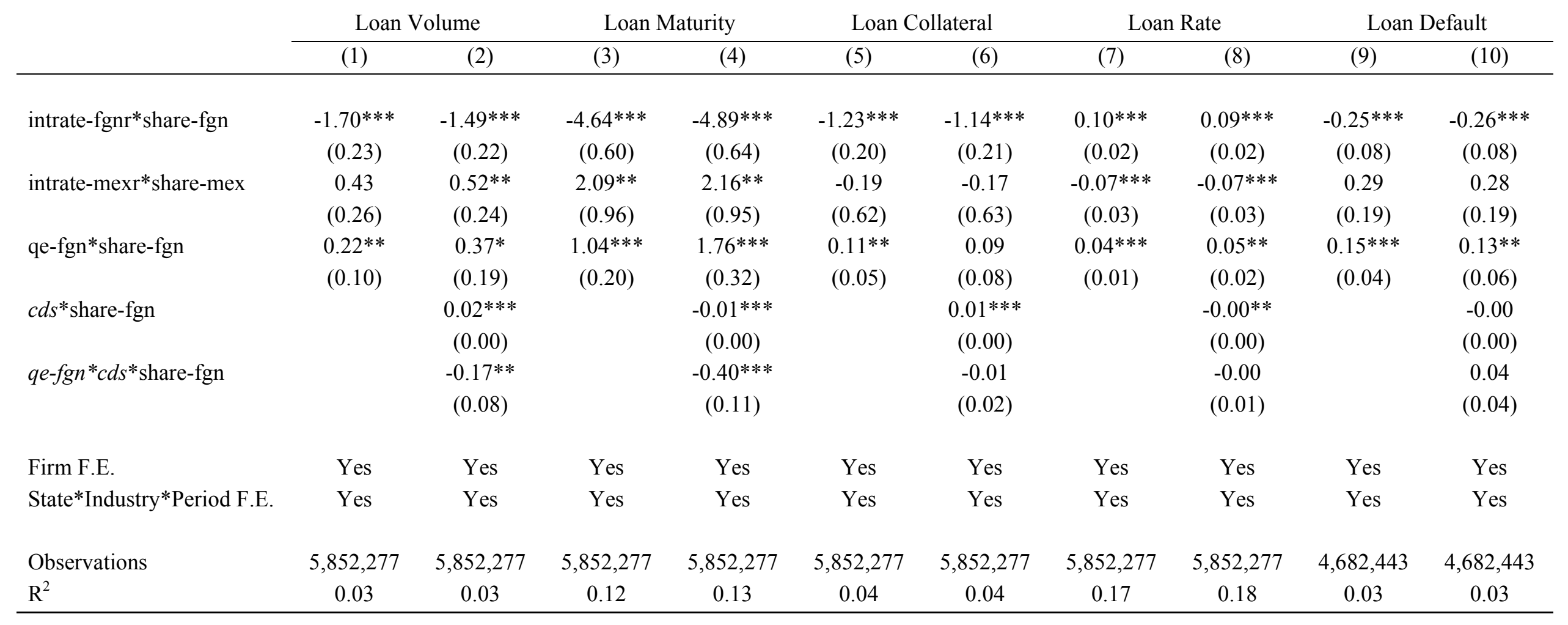

Table IAXIV

Asymmetric Impact of Expansions and Contractions of International Monetary Policies on Domestic Credit Margins

This table reports the estimates from OLS regressions for the period June 2001 to December 2015. Observations are at the firm-month level. The dependent variables are the firm's log total loan volume, log maturity, collateral rate, interest rate, and default rate 12-months ahead with a given bank in a given month. intrate-fgnr is the average of the residual of foreign overnight rates, weighted by the firm's share of loans from U.S., U.K., or Eurozone banks. share-fgn is the one-quarter-lagged share of loans from foreign banks. intrate-mexr is the residual of the Mexican overnight rate. share-mex is the one-quarter lagged share of loans from Mexican banks. qe-fgn is the average of foreign QEs, weighted by the firm's share of loans from U.S., U.K., or Eurozone banks. I (exp intcountry $)$ is an indicator variable that is equal to one if the residual of the overnight rate of country in period $t$ is positive. $I\left(\exp _{q e}\right)$ is an indicator for a positive annual real change in the net value of central bank assets, weighted by the firm's exposure to loans from banks from different countries. Other controls are listed in Section II of the main article. Standard errors are reported in parentheses and are clustered at the period level. $* * *, * * *$ significant at the $10 \%, 5 \%$ and $1 \%$ level respectively.

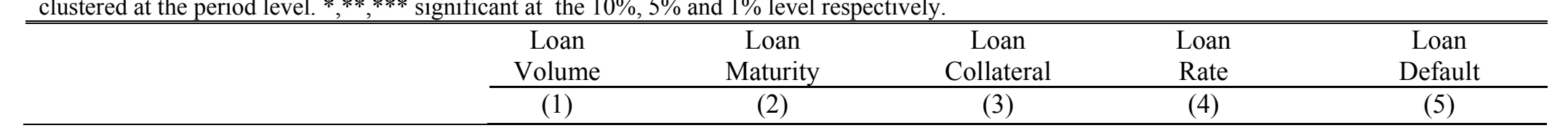


Table IAXV

Impact of Various Lags of International Monetary Policies on Domestic Credit Margins and Future Default (Firm Level)

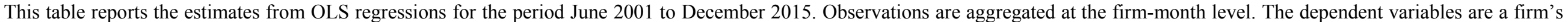

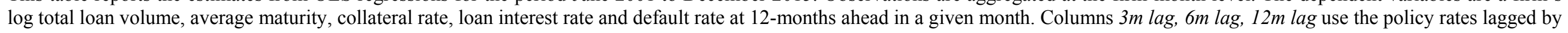

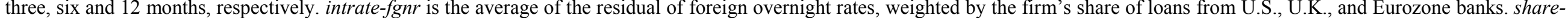

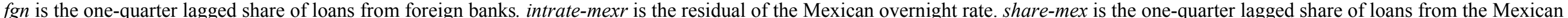

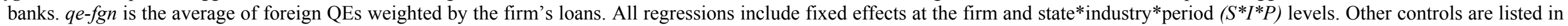

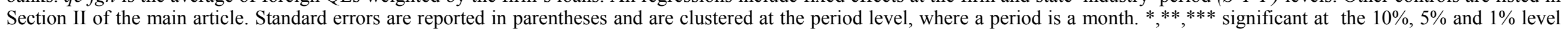
respectively.

\begin{tabular}{|c|c|c|c|c|c|}
\hline & $(0.56)$ & $(1.48)$ & $(0.38)$ & $(0.10)$ & $(0.18)$ \\
\hline \multirow[t]{2}{*}{ intrate-fgnr*share-fgn*I( $\left.\exp _{\text {intfrn }}\right)$} & 1.97 & -3.76 & $2.74 * * *$ & -0.28 & 0.16 \\
\hline & $(1.38)$ & $(3.38)$ & $(0.83)$ & $(0.17)$ & $(0.52)$ \\
\hline \multirow[t]{2}{*}{ intrate-mexr*share-mex } & 0.50 & $2.08 *$ & 0.06 & -0.12 & 0.28 \\
\hline & $(1.36)$ & $(1.14)$ & $(0.87)$ & $(0.15)$ & $(0.35)$ \\
\hline \multirow[t]{2}{*}{ intrate-mexr*share-mex $* I\left(\exp _{\text {intdom }}\right)$} & 2.17 & 0.20 & $1.61 * * *$ & 0.17 & 0.35 \\
\hline & $(7.06)$ & $(1.74)$ & $(0.53)$ & $(0.21)$ & $(0.45)$ \\
\hline \multirow[t]{2}{*}{ qe-fgn*share-fgn } & $0.99 * *$ & 0.98 & 0.12 & $-0.09 *$ & 0.60 \\
\hline & $(0.43)$ & $(0.96)$ & $(0.32)$ & $(0.05)$ & $(0.64)$ \\
\hline \multirow[t]{2}{*}{ qe-fgn*share-fgn $* I\left(\exp _{q e}\right)$} & -0.42 & 0.40 & -0.13 & 0.05 & $1.04 * * *$ \\
\hline & $(0.61)$ & $(1.38)$ & $(0.43)$ & $(0.09)$ & $(0.35)$ \\
\hline Firm F.E. & Yes & Yes & Yes & Yes & Yes \\
\hline State*Industry*Period F.E. & Yes & Yes & Yes & Yes & Yes \\
\hline Observations & $5,852,277$ & $5,852,277$ & $5,852,277$ & $5,852,277$ & $4,682,443$ \\
\hline $\mathrm{R}^{2}$ & 0.04 & 0.13 & 0.05 & 0.18 & 0.03 \\
\hline
\end{tabular}




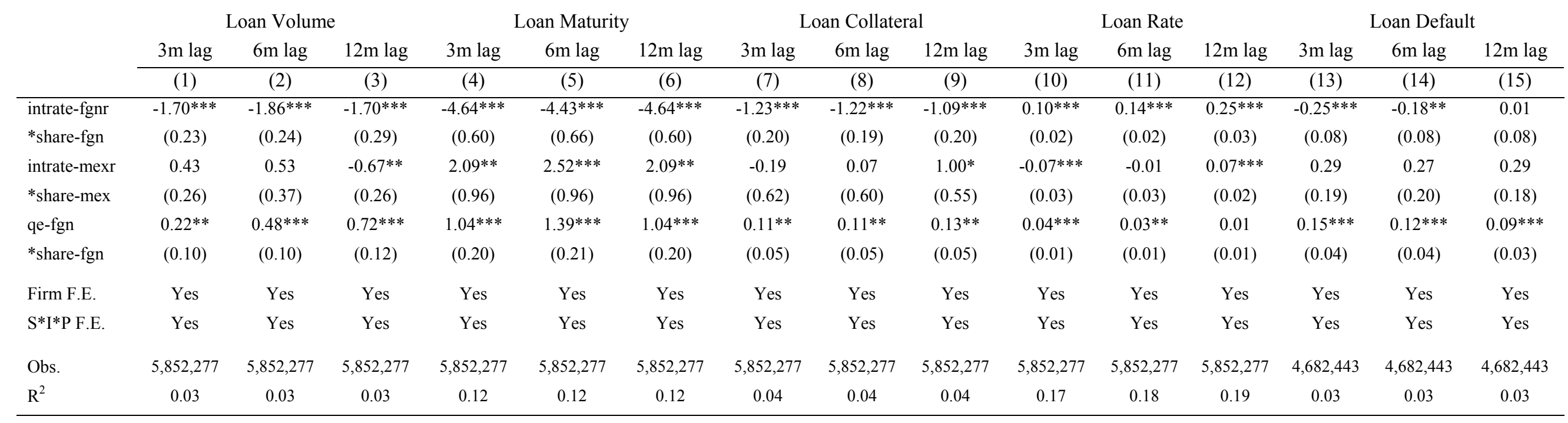




\section{Table IAXIV}

\section{Impact of Lagged-One-Year International Monetary Policies Domestic Firms' Real Variables}

This table reports the estimates from OLS regressions for the period 2001 to 2015 . Observations are at the firm-year level. The dependent variable in the first column is a proxy for firm survival due to loans in arrears. The next columns restrict the sample to firms that are observed in the loan-level data set and in the Orbis data set. The dependent variables are a firm's log liabilities (total, current, non-current), log total assets, log fixed assets, and log employment at year $t$. intrate ${ }^{Y-1}$-fgnr is the one-year lagged average of the foreign residual overnight rates, weighted by the firm's share of loans from U.S., U.K., or Eurozone banks. share ${ }^{Y}$-fgn is the one-year-lagged share of loans from foreign banks. Intrate ${ }^{Y-1}$ mexr is the one-year lagged residual of the Mexican overnight rate. share $e^{Y}$-mex is the one-year-lagged share of loans from Mexican banks. $q e^{Y-1}$-fgn is the one-year lag of the average of foreign QEs, weighted by the firm's share of loans from U.S., U.K., or Eurozone banks. All regressions include fixed effects at the firm and state*industry*year levels. Standard errors are reported in parentheses and are clustered at the state*year level. *,**,** significant at the $10 \%, 5 \%$ and $1 \%$ level respectively.

\begin{tabular}{|c|c|c|c|c|c|c|c|}
\hline & Exit & Liabilities & $\begin{array}{c}\text { Current } \\
\text { Liabilities }\end{array}$ & $\begin{array}{c}\text { Noncurrent } \\
\text { Liabilities }\end{array}$ & Assets & Fixed Assets & Employment \\
\hline & (1) & (2) & (3) & (4) & (5) & (6) & (7) \\
\hline \multirow[t]{2}{*}{ intrate $^{\mathrm{Y}-1}$-fgnr* share $^{\mathrm{Y}}$-fgn } & $0.88^{*}$ & $-1.22 * *$ & $-1.34^{* *}$ & $-1.32 * *$ & $-0.64 *$ & -0.00 & $-0.39^{*}$ \\
\hline & $(0.54)$ & $(0.41)$ & $(0.42)$ & $(0.49)$ & $(0.37)$ & $(0.37)$ & $(0.23)$ \\
\hline \multirow[t]{2}{*}{ intrate $^{\mathrm{Y}-1}-$ mexr $^{*}$ share $^{\mathrm{Y}}-\mathrm{mex}$} & -0.21 & 0.46 & 1.02 & -2.02 & $0.74 * *$ & $0.96^{* * *}$ & 0.30 \\
\hline & $(0.75)$ & $(0.80)$ & $(0.71)$ & $(2.69)$ & $(0.29)$ & $(0.28)$ & $(0.62)$ \\
\hline \multirow[t]{2}{*}{$\mathrm{qe}^{\mathrm{Y}-1}-$ fgn $^{*}$ share $^{\mathrm{Y}}$-fgn } & -0.13 & 0.03 & -0.14 & $1.78^{*}$ & 0.31 & 0.82 & -0.12 \\
\hline & $(0.09)$ & $(0.43)$ & $(0.47)$ & $(0.92)$ & $(0.29)$ & $(0.46)$ & $(0.11)$ \\
\hline Firm F.E. & Yes & Yes & Yes & Yes & Yes & Yes & Yes \\
\hline State*Industry*Year F.E. & Yes & Yes & Yes & Yes & Yes & Yes & Yes \\
\hline Observations & 744,221 & 13,945 & 13,918 & 6,923 & 14,563 & 14,563 & 13,838 \\
\hline $\mathrm{R}^{2}$ & 0.04 & 0.20 & 0.20 & 0.25 & 0.26 & 0.22 & 0.19 \\
\hline
\end{tabular}




\section{Table IAXVII}

Impact of International Monetary Policies on Real Variables re-scaled by Initial Local Firm Assets

This table reports the estimates from OLS regressions for the period 2001 to 2015. Observations are at the firm-year level for the sample of firms matched with Orbis data. The dependent variables are a firm's log loan volume, log liabilities, and log total assets, re-scaled by the firm's initial assets. intrate-fgnr is the average of the residual of foreign overnight rates weighted by firm's loans. share-fgn is the one-quarter lagged share of loans from foreign banks. intrate-mexr is the residual of Mexican overnight rate. share-mex is the one-quarter-lagged share of loans from Mexican banks. qe-fgn is the average of foreign QEs weighted by the firm's loans. All regressions include fixed effects at the firm, and state*industry*year levels. Standard errors are reported in parentheses and are clustered at the state*year level. $* * *, * * *$ significant at the $10 \%, 5 \%$ and $1 \%$ level respectively.

Loan Volume

(1)

intrate $^{\mathrm{Y}}$-fgnr* share $^{\mathrm{Y}}$-fgn

intrate $^{\mathrm{Y}}-\mathrm{mexr}^{*}$ share $^{\mathrm{Y}}-\mathrm{mex}$

$\mathrm{qe}^{\mathrm{Y}}$-fgn* share $^{\mathrm{Y}}$-fgn
$-1.64 *$

(0.94)

$-0.03$

(1.26)

0.35

(0.33)

Yes

Yes

42,574

0.24
Liabilities

(2)

$-1.03 * *$

(0.43)

0.38

(0.75)

Yes

Yes

13,943

0.20
Assets

(3)

$-0.69 * *$

0.66

Firm F.E.

Observations

$\mathrm{R}^{2}$
Yes

Yes

14,563 


\section{Table IAXVIII}

\section{Impact of International Monetary Policies on Real Variables of Small versus Large Domestic Firms}

This table reports the estimates from OLS regressions for the period 2001 to 2015. Observations are at the firm-year level. The dependent variable in the first column is a proxy for firm survival due to loans in arrears. The last six columns restrict the sample to firms that are observed in the loan-level data set and in the Orbis data set. The dependent variables are a firm's log liabilities (total, current, noncurrent), log total assets, log fixed assets, and log employment in a given year. intrate-fgnr is the average of the residual of foreign overnight rates weighted the by firm's loans. share-fgn is the one-quarter lagged share of loans from foreign banks. intrate-mexr is the residual of Mexican overnight rate. share-mex is the one-quarter lagged share of loans from the Mexican banks. qe-fgn is the average of foreign QEs weighted by firm's loans. Small (large) is an indicator for whether the borrower has fewer than (at least) 50 employees according to the information in the loan-level data set (following the definition of small firm used in Beck and Demirguc-Kunt (2006)). All regressions include fixed effects at the firm, and state*industry*year levels. Standard errors are reported in parentheses and are clustered at the state*year levels. *,**,*** significant at the $10 \%, 5 \%$ and $1 \%$ level respectively.

\begin{tabular}{|c|c|c|c|c|c|c|c|}
\hline & $\begin{array}{l}\text { Exit } \\
\text { (1) }\end{array}$ & $\begin{array}{c}\text { Liabilities } \\
\text { (2) }\end{array}$ & $\begin{array}{c}\text { Current } \\
\text { Liabilities } \\
\text { (3) }\end{array}$ & $\begin{array}{l}\text { Noncurrent } \\
\text { Liabilities } \\
\text { (4) }\end{array}$ & $\begin{array}{c}\text { Assets } \\
\text { (5) }\end{array}$ & $\begin{array}{c}\text { Fixed Assets } \\
\text { (6) }\end{array}$ & $\begin{array}{c}\text { Employment } \\
\text { (7) }\end{array}$ \\
\hline \multirow[t]{2}{*}{ intrate $^{\mathrm{Y}}$-fgnr*share ${ }^{\mathrm{Y}}$-fgn $*$ small } & $1.32 *$ & $-1.39 * *$ & $-1.37 * *$ & $-3.34 * *$ & $-1.04 * *$ & $-0.40 *$ & -0.53 \\
\hline & $(0.73)$ & $(0.49)$ & $(0.43)$ & $(1.16)$ & $(0.42)$ & $(0.24)$ & $(0.34)$ \\
\hline \multirow[t]{2}{*}{ intrate $^{\mathrm{Y}}$-fgnr* ${ }^{*}$ share ${ }^{\mathrm{Y}}$-fgn $*$ large } & -0.06 & -0.49 & -0.89 & 0.83 & 0.25 & 0.23 & -0.61 \\
\hline & $(0.22)$ & $(0.56)$ & $(0.67)$ & $(1.14)$ & $(0.56)$ & $(0.62)$ & $(0.72)$ \\
\hline \multirow[t]{2}{*}{ intrate $^{\mathrm{Y}}$-mexr* share $^{\mathrm{Y}}$-mex $*$ small } & $-1.40 * * *$ & 0.76 & $1.49 * *$ & -5.97 & $0.78 *$ & $1.72 * * *$ & -0.74 \\
\hline & $(0.36)$ & $(0.67)$ & $(0.57)$ & $(4.73)$ & $(0.37)$ & $(0.25)$ & $(1.52)$ \\
\hline \multirow[t]{2}{*}{ intrate $^{\mathrm{Y}}$-mexr* share $^{\mathrm{Y}}$-mex $*$ large } & 0.78 & 0.24 & 0.57 & 1.53 & $0.96 * *$ & $0.89 * * *$ & 0.78 \\
\hline & $(1.26)$ & $(0.68)$ & $(0.55)$ & $(3.20)$ & $(0.40)$ & $(0.20)$ & $(0.57)$ \\
\hline \multirow[t]{2}{*}{$\mathrm{qe}^{\mathrm{Y}}$-fgn* share ${ }^{\mathrm{Y}}$-fgn $*$ small } & 0.01 & 0.19 & 0.06 & $1.40 * *$ & 0.16 & $0.65 * * *$ & 0.04 \\
\hline & $(0.12)$ & $(0.21)$ & $(0.20)$ & $(0.49)$ & $(0.22)$ & $(0.19)$ & $(0.23)$ \\
\hline \multirow[t]{2}{*}{$\mathrm{qe}^{\mathrm{Y}}$-fgn* share $^{\mathrm{Y}}$-fgn $*$ large } & 0.10 & 0.09 & 0.09 & $-1.65 * * *$ & 0.00 & 0.68 & -0.26 \\
\hline & $(0.11)$ & $(0.39)$ & $(0.51)$ & $(0.39)$ & $(0.27)$ & $(0.43)$ & $(0.22)$ \\
\hline Firm F.E. & Yes & Yes & Yes & Yes & Yes & Yes & Yes \\
\hline State*Industry*Year F.E. & Yes & Yes & Yes & Yes & Yes & Yes & Yes \\
\hline Observations & 734,309 & 13,898 & 13,871 & 6,882 & 14,471 & 14,471 & 13,823 \\
\hline $\mathrm{R}^{2}$ & 0.03 & 0.20 & 0.20 & 0.26 & 0.26 & 0.22 & 0.20 \\
\hline
\end{tabular}

